Научная статья

УДК 591.69-82:598.22/.27 (571.5)

DOI: $10.18101 / 2542-0623-2021-1-23-65$

\title{
ГЕЛЬМИНТЫ ВОДНО-БОЛОТНЫХ ПТИЦ БАЙКАЛЬСКОЙ СИБИРИ: ТАКСОНОМИЧЕСКОЕ РАЗНООБРАЗИЕ И РАСПРЕДЕЛЕНИЕ ПО ХОЗЯЕВАМ
}

\author{
Ц. З. Доржиев, Е. Н. Бадмаева, Ж. Н. Дугаров
}

\section{(C) Доржиев Цыдыпжап Заятуевич}

доктор биологических наук, профессор,

Бурятский государственный университет имени Доржи Банзарова

Россия, 670000, г. Улан-Удэ, ул. Смолина, 24а

Институт общей и экспериментальной биологии СО РАН

Россия, 670047, г. Улан-Удэ, ул. Сахьяновой, 6

tsydypdor@mail.ru

\section{(C) Бадмаева Евгения Николаевна}

кандидат биологических наук, доцент, Бурятский государственный университет имени Доржи Банзарова Россия, 670000, г. Улан-Удэ, ул. Смолина, 24а

calidris03@gmail.com

\section{(с) Дугаров Жаргал Нимаевич}

кандидат биологических наук, старший научный сотрудник, Лаборатория паразитологии и экологии гидробионтов, Институт общей и экспериментальной биологии СО РАН Россия, 670047, г. Улан-Удэ, ул. Сахьяновой, 6 zhar-dug@biol.bscnet.ru

Аннотация. В заключительной статье по гельминтам водно-болотных птиц Байкальской Сибири проведен итоговый анализ таксономического состава указанных паразитов и распределение их по хозяевам. Материалы касаются 63 видов птиц, относящихся к 7 отрядам: гусеобразные Anseriformes - 17 видов, гагарообразные Gaviiformes - 2 вида, пеликанообразные Pelecaniformes - 1 вид (большой баклан), аистообразные Ciconiiformes - 1 вид (серая цапля), поганкообразные Podicipediformes - 3 вида, журавлеобразные Gruiformes - один вид (лысуха), ржанкообразные Charadriiformes - 38 видов.

У водно-болотных птиц Байкальской Сибири всего выявлено 243 вида гельминтов из 4 классов, 47 семейств, 113 родов. Наиболее богатым в таксономическом отношении оказался класс трематод - 107 видов, распределенных по 10 отрядам, 14 семействам и 50 родам. Далее идет класс цестодов, представленный 94 видами из 3 отрядов, 9 семейств и 42 родов. Нематодов выявлено немного - 36 видов из 5 отрядов, 12 семейств и 18 родов, еще меньше скребней - 5 видов, представляющих один отряд, одно семейство и три рода.

Приведен видовой состав гельминтов по всем 63 видам птиц. Недостаточность материала по многим видам не позволила выявить общую картину зараженности их гельминтами, лишь по некоторым видам уток, поганкам, куликам и чайкам получены хорошие результаты. 
Ключевые слова: гельминты; цестоды; трематоды; нематоды; скребни; паразиты водно-болотных птиц; оз. Байкал; Байкальская Сибирь.

Благодарности. Работа выполнена при частичной финансовой поддержке гранта на проведение инновационных научных исследований Бурятского государственного университета имени Доржи Банзарова в 2021 г.

\section{Для цитирования}

Доржиев Ц. 3., Бадмаева Е. Н., Дугаров Ж. Н. Гельминты водно-болотных птиц Байкальской Сибири: таксономическое разнообразие и распределение по хозяевам // Природа Внутренней Азии. Nature of Inner Asia. 2021. № 1(17). С. 23-65.

DOI: 10.18101/2542-0623-2021-1-23-65

\section{Введение}

Целенаправленные исследования гельминтов птиц в последние несколько десятилетий на юге Восточной Сибири, также как и в целом в Сибири, практически прекратились. Наиболее интенсивно они изучались во многих районах Сибири во второй половине прошлого столетия [Быховская, Рыжиков, 1958; Мамаев, 1959; Контримавичус, Бахметьева, 1960; Сергеева, 1970, 1971; Белопольская, 1971; Губанов, 1971; Губанов, Сергеев, 1971; Губанов, Федоров, 1971; Спасская, Спасский, 1971; Рыжиков и др., 1973, 1974; Филимонова, 1973; Антрашкевич, Сонин, 2004; Атрашкевич, 2018]. В этот же период специальные исследования паразитов птиц проводились в Байкальском регионе и на прилегающих к нему территориях Северной Монголии [Мамаев, 1959; Danzan, 1964; Масарновский, Скрябин, 1979; Некрасов, Жатканбаева, 1982; Некрасов, Санжиева, Егоров, 1982; Некрасов, Тимошенко, Санжиева, 1985, 1995; Некрасов, Санжиева, 1988, 1996; Тимошенко и др., 1988; Некрасов, 1989; 2000; Тимошенко, 1990; Ganzorig, Danzan, 1990; Подковыров и др., 1991; Пронин и др., 1991, 2000; Тупицын, Тимошенко, 1996; Некрасов и др., 1982, 1985, 1999а,б, 2001; Санжиева, 2000; Балданова, Пронин, 2001; Ganzorig 2016; и др.]. Большая часть этих работ посвящена массовым видам птиц оз. Байкал.

В целом гельминты птиц Байкальской Сибири остаются еще недостаточно изученными, некоторые виды представлены единичными особями, по многим нет никаких сведений. Имеющиеся материалы оказались разбросанными по разным статьям, за исключением списка гельминтов А. В. Некрасова [2000]. Поэтому нами была сделана попытка обобщить эти данные сначала по отдельным таксономическим группам птиц [Доржиев, Бадмаева, Дугаров, 2019а,б, 2020а,б], затем дать общий аннотированный список гельминтов и их распределение по хозяевам. Однако анализ литературных источников показал, что большая часть сведений относится к водно-болотным птицам, паразиты наземных птиц остаются крайне слабоизученными. Поэтому мы ограничились водно-болотными птицами, хотя по ним материал также недостаточный, за исключением отдельных видов уток, чаек и некоторых куликов.

Тем не менее общий аннотированный список гельминтов и распределение их по хозяевам актуален, поскольку он выявит степень их изученности, несомненно, пригодится при дальнейших исследованиях гельминтов птиц региона. 
Ц. 3. Доржсиев, Е. Н. Бадмаева, Ж. Н. Дугаров. Гельминты водно-болотных птиц Байкальской Сибири: таксономическое разнообразие и распределение по хозяевам

В настоящей статье дается таксономический список гельминтов и их распределение по видам хозяев - водно-болотным птицам Байкальского региона.

Статья посвящается светлой памяти Александра Васильевича Некрасова, канд. вет. наук, отдавшего значительную часть научной деятельности изучению гельминтов птиц Байкальского региона. Он работал в лаборатории паразитологии Института общей и экспериментальной биологии СО РАН под руководством заведующего лабораторией д-ра биол. наук, профессора Н. М. Пронина, известного паразитолога Сибири.

\section{Материал и методика}

Основой данной статьи послужили литературные сведения о гельминтах водно-болотных птиц оз. Байкал и прилегающих территорий Селенгинского Забайкалья. Подавляющая часть материала собрана на оз. Байкал (Малое море, Северобайкальский сор, Чивыркуйский залив) и в устьях рек основных его притоков (р. Селенга, Верхняя Ангара, Кичера), а также на оз. Гусиное, в долинах рек Селенга и Баргузин. Всего приводятся данные по гельминтам 63 видов 7 отрядов водно-болотных птиц региона, что составляет $42 \%$ видового их состава (табл. 1 ).

Таблииа 1

Количество исследованных видов разных отрядов водно-болотных птиц Байкальской Сибири

\begin{tabular}{|l|c|c|}
\hline \multicolumn{1}{|c|}{ Отряд } & $\begin{array}{c}\text { Всего видов } \\
\text { в регионе, абс. }\end{array}$ & $\begin{array}{c}\text { Исследовано видов, } \\
\text { абс., \% }\end{array}$ \\
\hline Гусеобразные Anseriformes & 37 & $17(45,9)$ \\
\hline Гагарообразные Gaviiformes & 3 & $2(66,7)$ \\
\hline Пеликанообразные Pelecaniformes & 2 & $1(50,0)$ \\
\hline Аистообразные Ciconiiformes & 8 & $1(12,5)$ \\
\hline Поганкообразные Podicipediformes & 5 & $3(60,0)$ \\
\hline Журавлеобразные Gruiformes & 14 & $1(7,1)$ \\
\hline Ржанкообразные Charadriiformes & 81 & $38(46,9)$ \\
\hline Всего: & 150 & $63(42,0)$ \\
\hline
\end{tabular}

Объем материала разный, обследовано от 1 до 60 особей по разным видам. Из отряда гусеобразных данные представлены по следующим видам: огарь Tadorna ferruginea (обследовано 6 особей), свиязь Anas Penelope (5), касатка A. falcate (3), серая утка $A$. strepera (39), чирок-свистунок A.crecca (60), кряква $A$. platyrhynchos (60), черная кряква A. zonorhyncha (4), шилохвость $A$. acuta (12), чирок-трескунок A. querquedula (3), широконоска A. clypeata (23), красноголовый нырок Aythya ferina (45), хохлатая чернеть A. fuligula (24), горбоносый турпан Melanitta deglandi (1), гоголь Bucephala clangula (1), луток Mergus albellus (6), длинноносый крохаль $M$. serrator (12), большой крохаль M. merganser (34).

Из гагарообразных исследованы краснозобая Gavia stellata (5) и чернозобая гагары G. arctica (2), пеликанообразные - большой баклан Phalacrocorax carbo (3), аистообразные - серая цапля Ardea cinerea (2), поганкообразные - чомга 
Podiceps cristatus (44), черношейная P. nigricollis (3) и красношейная поганки P. auritus (7), журавлеобразные - лысуха Fulica atra (28).

Наибольшим представительством отличался отряд ржанкообразные: чибис Vanellus vanellus (вскрыто 50 особей), бурокрылая ржанка Pluvialis fulva (1), галстучник Charadrius hiaticula (4), малый зуек C. dubius (3), камнешарка Arenaria interpres (1), вальдшнеп Scolopax rusticola (1), азиатский бекас Gallinago stenura (5), лесной дупель G. megala (1), бекас G. gallinago (8), азиатский бекасовидный веретенник Limnodromus semipalmatus (1), большой веретенник Limosa limosa (28), малый веретенник L. lapponica (1), кроншнеп-малютка Numenius minutus (3), средний кроншнеп N. Phaeopus (1), большой кроншнеп N. Arquata (3), щеголь Tringa erythropus (21), поручейник T. stagnatilis (44), большой улит T. nebularia (14), черныш T. ochropus (3), фифи T. glareola (32), сибирский пепельный улит Heteroscelus brevipes (3), перевозчик Actitis hypoleucos (6), мородунка Xenus cinereus (2), круглоносый плавунчик Phalaropus lobatus (1), кулик-воробей Calidris minuta (12), длиннопалый песочник C. subminuta (2), белохвостый песочник C. temminckii (1), краснозобик C. ferruginea (6), чернозобик C. alpine (1), острохвостый песочник C. acuminate (1), турухтан Phylomachus pugnax (2), сизая Larus canus (199), монгольская L. mongolicus (890), озерная L. ridibundus (44) и малая чайки L. minutus (5), чеграва Hydroprogne caspia (1), речная Sterna hirundo (13) и белокрылая крачки Chlidonias leucopterus (7).

При составлении списка гельминтов мы не придерживались строго современной номенклатуры. Он приведен по различным источникам разных лет [Скрябин и др., 1949, 1951, 1952,1954; Шевцов, Заскинд, 1960; Быховская-Павловская, 1953, 1962; Матевосян, 1963; Спасская, 1966; Смогоржевская, 1976; Рыжиков, Толкачева, 1981; Определитель трематод..., 1985, 1986; Bondarenko, Kontrimavichus, 2018].

Результаты исследований и обсуждение

ТАКСОНОМИЧЕСКИЙ СОСТАВ ГЕЛЬМИНТОВ

КЛАСС ЦЕСТОДА - CESTODA RUDOLPHI, 1808

\section{Отряд Pseudophyllidea Carus, 1863}

\section{Семейство Diphyllobothriidae Lühe, 1910}

\section{Diphyllobothrium dendriticum (Nitzsch, 1824)}

Хозяин: Гусеобразные: длинноносый крохаль, большой крохаль. Гагарообразные: краснозобая гагара, чернозобая гагара. Поганкообразные: чомга, красношейная поганка. Ржанкообразные: сизая чайка, монгольская чайка, озерная чайка. Места обнаружения: оз. Байкал.

\section{Diphyllobothrium ditremum (Creplin, 1825)}

Хозяин: Гагарообразные: краснозобая гагара. Ржанкообразные: сизая чайка, монгольская чайка, озерная чайка. Место обнаружения: оз. Байкал и устья байкальских рек. 


\section{Семейство Ligulidae Claus, 1868}

3. Ligula intestinalis (Linnaeus, 1758)

Хозяин: Гусеобразные: длинноносый крохаль, большой крохаль. Поганкообразные: чомга. Пеликанообразные: большой баклан. Ржанкообразные: сизая чайка, монгольская чайка, озерная чайка. Место обнаружения: оз. Байкал.

4. Ligula colymbi Zeder, 1803

Хозяин: Гагарообразные: краснозобая гагара. Поганкообразные: чомга. Пеликанообразные: большой баклан. Ржанкообразные: сизая чайка. Место обнаружения: о3. Байкал и устья байкальских рек.

\section{Digramma interrupta (Rudolphi, 1910)}

Хозяин: Поганкообразные: чомга. Место обнаружения: оз. Байкал и устья байкальских рек.

6. Schistocephalus solidus (Müller, 1776)

Хозяин: Гусеобразные: длинноносый крохаль, большой крохаль. Гагарообразные: краснозобая гагара. Поганкообразные: чомга. Ржанкообразные: монгольская чайка. Место обнаружения: оз. Байкал и устья байкальских рек.

7. Schistocephalus nemachili (Dubinina, 1959)

Хозяин: Гусеобразные: большой крохаль. Поганкообразные: чомга. Место обнаружения: устье р. Верхняя Ангара.

\section{Отряд Tetraphyllidea Carus, 1868}

\section{Семейство Tetrabothriidae Linton, 1891}

\section{Tetrabothrius macrocephalus Rudolphi, 1810}

Хозяин: Гагарообразные: краснозобая гагара. Поганкообразные: красношейная поганка. Место обнаружения: устья байкальских рек.

\section{Отряд Cyclophyllidea Beneden in Braun, 1900}

\section{Семейство Dilepididae Fuhrmann, 1907}

\section{Paradilepis scolecina (Rudolphi, 1819)}

Хозяин: Пеликанообразные: большой баклан. Место обнаружения: оз. Байкал и устья байкальских рек.

10. Dilepis undula (Schrank, 1788)

Хозяин: Ржанкообразные: кроншнеп-малютка. Место обнаружения: устья байкальских рек.

11. Dilepis glareola (Dubinina, 1953)

Хозяин: Ржанкообразные: фифи. Место обнаружения: дельта р. Селенги.

12. Gryporhynchus pusillus (Nordmann, 1832)

Хозяин: Аистообразные: серая цапля. Место обнаружения: долина р. Баргузин.

13. Unciunia ciliata (Fuhrmann, 1913)

Хозяин: Гусеобразные: серая утка, хохлатая чернеть. Место обнаружения: оз. Байкал и устья байкальских рек. 


\section{Lateriporus gredleri Sailov, 1962}

Хозяин: Ржанкообразные: монгольская чайка. Место обнаружения: оз. Байкал.

15. Lateriporus clerci (Johnston, 1912)

Хозяин: Гусеобразные: чирок-свистунок. Поганкообразные: чомга, красношейная поганка. Ржанкообразные: сизая чайка, монгольская чайка, озерная чайка. Место обнаружения: оз. Байкал и устья байкальских рек.

16. Lateriporus skrjabini Mathevossian, 1946

Хозяин: Гусеобразные: чирок-свистунок, кряква, хохлатая чернеть. Место обнаружения: оз. Байкал и устья байкальских рек.

17. Lateriporus teres (Krabbe, 1869)

Хозяин: Гусеобразные: чирок-свистунок, хохлатая чернеть. Ржанкообразные: монгольская чайка, озерная чайка, речная крачка. Место обнаружения: оз. Байкал и устья байкальских рек.

18. Panuwa guiarti (Tseng, 1932)

Хозяин: Ржанкообразные: малый зуек. Место обнаружения: долина р. Селенги.

19. Platyscolex ciliata (Fuhrmann, 1931)

Хозяин: Гусеобразные: серая утка, хохлатая чернеть. Поганкообразные: чомга. Место обнаружения: оз. Байкал и устья байкальских рек.

20. Paricterotaenia porosa (Rudolphi, 1810)

Хозяин: Ржанкообразные: сизая чайка, монгольская чайка, озерная чайка. Место обнаружения: оз. Байкал и устья байкальских рек.

21. Paricterotaenia sternina (Krabbe, 1869)

Хозяин: Ржанкообразные: сизая чайка, монгольская чайка, озерная чайка. Место обнаружения: 03. Байкал и устья байкальских рек.

22. Polycercus paradoxa (Rudolphi, 1802)

Хозяин: Ржанкообразные: малый зуек, азиатский бекас. Место обнаружения: долина р. Баргузин.

23. Pseudanomotaenia micracantha (Krabbe, 1869)

Хозяин: Пеликанообразные: большой баклан. Ржанкообразные: сизая чайка, монгольская чайка. Место обнаружения: оз. Байкал и устья байкальских рек.

\section{Pseudanomotaenia paramicrorhyncha (Dubinina, 1953)}

Хозяин: Ржанкообразные: малый зуек, азиатский бекас, сибирский пепельный улит, фифи, краснозобик, турухтан. Место обнаружения: дельта и долина р. Селенги.

\section{Семейство Choanotaeniidae Mathevossian, 1953}

\section{Choanotaenia porosa (Rudolphi, 1819)}

Хозяин: Ржанкообразные: сизая чайка, монгольская чайка, озерная чайка, речная крачка. Место обнаружения: оз. Байкал.

26. Anomotaenia clavigera (Krabbe, 1869)

Хозяин: Ржанкообразные: малый зуек, большой улит, фифи, перевозчик, круглоносый плавунчик. Место обнаружения: долина р. Селенги.

27. Anomotaenia citrus (Krabbe, 1869)

Хозяин: Ржанкообразные: малый зуек, вальдшнеп, азиатский бекас, щеголь, 
большой улит, фифи, сибирский пепельный улит, перевозчик, мородунка, куликворобей обыкновенный, бекас. Место обнаружения: долина р. Селенги.

28. Anomotaenia globulus (Wedl, 1855)

Хозяин: Ржанкообразные: бурокрылая ржанка, черныш, сибирский пепельный улит, перевозчик, кулик-воробей. Место обнаружения: долина р. Селенги.

29. Anomotaenia microphallos (Krabbe, 1869)

Хозяин: Ржанкообразные: чибис, бурокрылая ржанка. Место обнаружения: долина

р. Селенги.

30. Anomotaenia microrhyncha (Krabbe, 1869)

Хозяин: Ржанкообразные: чибис. Место обнаружения: дельта р. Селенги.

31. Anomotaenia nymphaea (Schrank, 1790)

Хозяин: Ржанкообразные: кроншнеп-малютка, средний кроншнеп, большой кроншнеп, сибирский пепельный улит, перевозчик, кулик-воробей. Место обнаружения: долина р. Селенги.

32. Anomotaenia ancora Mamaev, 1959

Хозяин: Ржанкообразные: азиатский бекас. Место обнаружения: долина р. Селенги.

33. Anomotaenia stentorea (Fröhlich, 1802)

Хозяин: Ржанкообразные: чибис. Место обнаружения: долина р. Селенги.

34. Anomotaenia mollis (Volz, 1900)

Хозяин: Ржанкообразные: галстучник, малый зуек, сибирский пепельный улит. Место обнаружения: устья байкальских рек, долина р. Селенги.

35. Anomotaenia tringae (Burt, 1940)

Хозяин: Ржанкообразные: чибис, галстучник, малый зуек, азиатский бекас, большой улит, фифи, сибирский пепельный улит, краснозобик, турухтан. Место обнаружения: долина р. Селенги.

36. Kowalewskiella longiannulata Baczynska, 1914

Хозяин: Ржанкообразные: поручейник, перевозчик. Место обнаружения: дельта p. Селенги.

37. Kowalewskiella cingulifera (Krabbe, 1869)

Хозяин: Ржанкообразные: длиннопалый песочник. Место обнаружения: дельта и долина р. Селенги.

38. Sacciuterina paradoxa (Rudolphi, 1802)

Хозяин: Ржанкообразные: турухтан. Место обнаружения: долина р. Селенги.

39. Trichocephaloides megalocephala (Krabbe, 1869)

Хозяин: Ржанкообразные: кулик-воробей, белохвостый песочник, краснозобик, чернозобик. Место обнаружения: долина р. Селенги.

40. Liga brevis (Linstow, 1884)

Хозяин: Ржанкообразные: бурокрылая ржанка. Место обнаружения: долина р. Селенги.

\section{Семейство Paruterinidae Fuhrmann, 1907}

\section{Cladotaenia globifera (Batsch, 1786)}

Хозяин: Поганкообразные: чомга, черношейная поганка. Место обнаружения: оз. Байкал и устья байкальских рек, долина р. Баргузин. 


\section{Семейство Нymenolepididae (Ariola, 1899)}

42. Aploparaksis filum (Goeze, 1782)

Хозяин: Ржанкообразные: азиатский бекас, перевозчик, большой улит, черныш, фифи, мородунка, круглоносый плавунчик. Место обнаружения: долина р. Селенги.

43. Aploparaksis brachyphallos (Krabbe, 1869)

Хозяин: Ржанкообразные: кулик-воробей, белохвостый песочник. Место обнаружения: долина р. Селенги.

44. Aploparaksis crassirostris (Krabbe, 1869)

Хозяин: Ржанкообразные: малый зуек, азиатский бекас, обыкновенный бекас, кроншнеп-малютка, фифи, перевозчик, мородунка, кулик-воробей, белохвостый песочник, краснозобик, турухтан. Место обнаружения: долины р. Селенга, Баргузин.

45. Aploparaksis diagonalis Spassky et Bobova, 1961

Хозяин: Ржанкообразные: кулик-воробей, чернозобик. Место обнаружения: долина р. Селенги.

46. Aploparaksis furcigera (Rudolphi, 1819)

Хозяин: Гусеобразные: серая утка, чирок-свистунок, кряква, красноголовый нырок, хохлатая чернеть. Ржанкоообразные: монгольская чайка. Место обнаружения: оз. Байкал и устья байкальских рек.

47. Aploparaksis hirsuta (Krabbe, 1882)

Хозяин: Ржанкообразные: фифи, перевозчик, кулик-воробей, белохвостый песочник. Место обнаружения: долина р. Селенги.

48. Aploparaksis mamaevi (Bondarenko, 1966)

Хозяин: Ржанкообразные: обыкновенный бекас, фифи. Место обнаружения: долина р. Баргузин.

49. Aploparaksis orientalis Spassky et Bobova, 1961

Хозяин: Ржанкообразные: черныш. Место обнаружения: долина р. Селенги.

50. Aploparaksis oschmarini Spassky et Bobova, 1961

Хозяин: Ржанкообразные: черныш. Место обнаружения:

51. Aploparaksis pseudofilum (Clerc, 1902)

Хозяин: Ржанкообразные: белохвостый песочник. Место обнаружения: долина р. Селенги.

52. Aploparaksis sachalinensis Krotov, 1952

Хозяин: Ржанкообразные: малый зуек, азиатский бекас, обыкновенный бекас, щеголь, большой улит, черныш, фифи, сибирский пепельный улит, куликворобей, белохвостый песочник, краснозобик, острохвостый песочник. Место обнаружения: долина р. Селенги.

53. Aploparaksis sanjuanensis Tubangui et Masilungan, 1937

Хозяин: Ржанкообразные: малый зуек, азиатский бекас, обыкновенный бекас, большой улит, фифи, мородунка, кулик-воробей, острохвостый песочник. Место обнаружения: долина р. Селенги.

54. Aploparaksis secessivus Gubanov et Mamaev, 1959

Хозяин: Ржанкообразные: обыкновенный бекас, черныш, фифи, перевозчик, кулик-воробей. Место обнаружения: долина р. Селенги.

55. Aploparaksis spinosus (Bondarenko, 1966)

Хозяин: Ржанкообразные: обыкновенный бекас. Место обнаружения: долина р. Селенги. 
Ц. 3. Доржсиев, Е. Н. Бадмаева, Ж. Н. Дугаров. Гельминты водно-болотных птиц Байкальской Сибири: таксономическое разнообразие и распределение по хозяевам

56. Aploparaksis stricta Spassky, 1961

Хозяин: Ржанкообразные: кулик-воробей. Место обнаружения: долина р. Селенги.

57. Cloacotaenia megalops (Nitzsch in Creplin, 1829)

Хозяин: Гусеобразные: свиязь, серая утка, чирок-свистунок, кряква, широконоска, красноголовый нырок, хохлатая чернеть, гоголь. Ржанкообразные: сизая чайка, монгольская чайка, озерная чайка. Место обнаружения: оз. Байкал и устья байкальских рек.

58. Confluaria furcifera (Krabbe, 1869)

Хозяин: Поганкообразные: чомга, красношейная поганка. Место обнаружения: оз. Байкал и устья байкальских рек.

59. Confluaria podicipina (Szymanski, 1905)

Хозяин: Поганкообразные: чомга. Место обнаружения: оз. Байкал и устья байкальских рек.

60. Dicranotaenia coronula (Dujardin, 1845)

Хозяин: Гусеобразные: серая утка, чирок-свистунок, кряква, широконоска, хохлатая чернеть. Место обнаружения: оз. Байкал и устья байкальских рек.

61. Dicranotaenia sp.

Хозяин: Гусеобразные: кряква. Место обнаружения: оз. Байкал и устья байкальских рек.

62. Diorchis bulbodes Mayhew, 1929

Хозяин: Гусеобразные: касатка, кряква, широконоска, красноголовый нырок, хохлатая чернеть. Ржанкообразные: озерная чайка. Место обнаружения: оз. Байкал и устья байкальских рек.

63. Diorchis elisae (Skrjabin, 1914)

Хозяин: Гусеобразные: огарь, серая утка, кряква, хохлатая чернеть. Место обнаружения: оз. Байкал и устья байкальских рек.

64. Diorchis lintoni Johri, 1939

Хозяин: Гусеобразные: серая утка, кряква, красноголовый нырок. Место обнаружения: оз. Байкал и устья байкальских рек.

65. Diorchis ransomi Schultz, 1940

Хозяин: Гусеобразные: серая утка, чирок-свистунок, кряква, широконоска, красноголовый нырок, хохлатая чернеть, горбоносый турпан. Поганкообразные: чомга. Журавлеобразные: лысуха. Ржанкообразные: сизая чайка. Место обнаружения: оз. Байкал и устья байкальских рек, долина р. Баргузин.

66. Diorchis sobolevi Spasskaja, 1950

Хозяин: Гусеобразные: кряква, красноголовый нырок, хохлатая чернеть. Журавлеобразные: лысуха. Место обнаружения: оз. Байкал и устья байкальских рек.

67. Diorchis stefanskii Czaplinski, 1956

Хозяин: Гусеобразные: серая утка, кряква, красноголовый нырок, хохлатая чернеть. Журавлеобразные: лысуха. Место обнаружения: оз. Байкал и устья байкальских рек.

68. Diploposthe laevis (Bloch, 1782)

Хозяин: Гусеобразные: чирок-свистунок, широконоска, красноголовый нырок, хохлатая чернеть. Место обнаружения: оз. Байкал и устья байкальских рек.

69. Dubininolepis rostellata (Abilgaard, 1790)

Хозяин: Гагарообразные: краснозобая гагара. Место обнаружения: оз. Байкал. 


\section{Echinocotyle rosseteri Blanchard, 1891}

Хозяин: Гусеобразные: чирок-свистунок, хохлатая чернеть. Место обнаружения: оз. Байкал и устья байкальских рек.

71. Echinocotyle clerci Mathevossian et Krotov, 1949

Хозяин: Гусеобразные: чирок-свистунок, широконоска, хохлатая чернеть. Место обнаружения: оз. Байкал и устья байкальских рек.

\section{Echinocotyle magnisaccis (Meggitt, 1927)}

Хозяин: Ржанкообразные: чибис, большой веретенник. Место обнаружения: дельта р. Селенги.

73. Echinocotyle uralensis Clerc, 1902

Хозяин: Ржанкообразные: чибис, турухтан. Место обнаружения: дельта и долина р. Селенги.

74. Echinocotyle nitida (Clerc, 1902, 1903)

Хозяин: Ржанкообразные: азиатский бекас, малый веретенник, перевозчик, куликворобей. Место обнаружения: долина р. Селенги.

75. Fimbriaria fasciolaris (Pallas, 1781)

Хозяин: Гусеобразные: огарь, серая утка, кряква, широконоска, красноголовый нырок, длинноносый крохаль, большой крохаль. Место обнаружения: оз. Байкал и устья байкальских рек, долина р. Баргузин.

76. Gastrotaenia dogieli (Gynezinskaja, 1944)

Хозяин: Гусеобразные: чирок-свистунок, широконоска, красноголовый нырок, хохлатая чернеть. Ржанкообразные: монгольская чайка. Место обнаружения: оз. Байкал и устья байкальских рек.

\section{Microsomacanthus abortiva (Linstow, 1904)}

Хозяин: Гусеобразные: серая утка, чирок-свистунок, кряква, красноголовый нырок. Место обнаружения: оз. Байкал и устья байкальских рек.

78. Microsomacanthus compressa (Linton, 1892)

Хозяин: Гусеобразные: серая утка, чирок-свистунок, кряква. Место обнаружения: о3. Байкал и устья байкальских рек.

\section{Microsomacanthus parvula (Kowalewski, 1904)}

Хозяин: Гусеобразные: кряква, хохлатая чернеть. Место обнаружения: оз. Байкал, долина р. Баргузин.

80. Microsomacanthus paramicrosoma (Gasowska, 1931)

Хозяин: Гусеобразные: луток. Место обнаружения: оз. Байкал.

81. Nadejdolepis nitida (Krabbe, 1869)

Хозяин: Ржанкообразные: азиатский бекас, обыкновенный бекас, малый веретенник, перевозчик, кулик-воробей, длиннопалый песочник, белохвостый песочник. Место обнаружения: оз. Байкал и устья байкальских рек, долина р. Селенги.

82. Myxolepis collaris (Batsch, 1786)

Хозяин: Гусеобразные: кряква. Место обнаружения: долина р. Баргузин.

83. Passerilepis crenata (Goeze, 1782)

Хозяин: Ржанкообразные: малый веретенник, перевозчик. Место обнаружения: долина р. Селенги.

84. Retinometra longicirrosa (Fuhrmann, 1906)

Хозяин: Гусеобразные: серая утка, чирок-свистунок, кряква. Место обнаружения: оз. Байкал и устья байкальских рек, долина р. Баргузин. 
Ц. З. Доржиев, Е. Н. Бадмаева, Ж. Н. Дугаров. Гельминты водно-болотных птиц Байкальской Сибири: таксономическое разнообразие и распределение по хозяевам

85. Retinometra skrjabini (Mathevossian, 1945)

Хозяин: Гусеобразные: широконоска. Место обнаружения: оз. Байкал и устья байкальских рек.

86. Skrjabinoparaksis tatianae Krotov, 1949

Хозяин: Гусеобразные: широконоска. Место обнаружения: оз. Байкал.

87. Sobolevicanthus gracilis (Zeder, 1803)

Хозяин: Гусеобразные: касатка, серая утка, чирок-свистунок, кряква, хохлатая чернеть, гоголь. Место обнаружения: оз. Байкал.

88. Sobolevicanthus fragilis (Krabbe, 1869)

Хозяин: Гусеобразные: гоголь. Место обнаружения: оз. Байкал и устья байкальских рек.

89. Sobolevicanthus krabbeella (Hughes, 1940)

Хозяин: Гусеобразные: чирок-свистунок, широконоска. Место обнаружения: оз. Байкал.

90. Sobolevicanthus octacantha (Krabbe, 1869)

Хозяин: Гусеобразные: чирок-свистунок, широконоска. Место обнаружения: оз. Байкал и устья байкальских рек.

91. Wardium fusa (Krabbe, 1869)

Хозяин: Ржанкообразные: чибис, сизая чайка, монгольская чайка, озерная чайка. Место обнаружения: оз. Байкал и устья байкальских рек.

\section{Семейство Amabiliidae Braun, 1900}

92. Tatria biremis Kowalewski, 1904

Хозяин: Поганкообразные: чомга, черношейная поганка. Место обнаружения: оз. Байкал и устья байкальских рек.

\section{Семейство Progynotaeniidae Burt, 1939}

\section{Progynotaenia odhneri Nybelin, 1914}

Хозяин: Ржанкообразные: кулик-воробей, турухтан. Место обнаружения: долина р. Селенги.

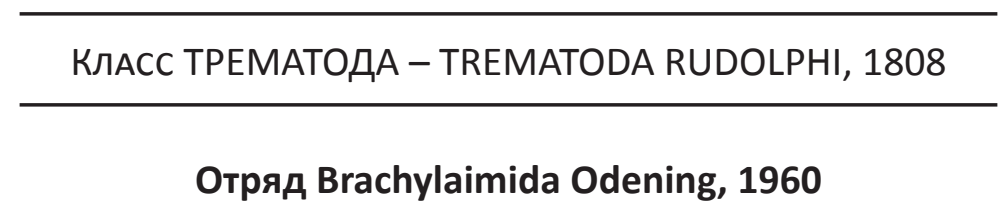

\section{Семейство Leucochloridiidae (Sinitsin, 1931)}

\section{Leucochloridium actitis McIntosh, 1932}

Хозяин: Ржанкообразные: чибис, малый зуек, азиатский бекас, кроншнеп-малютка, большой кроншнеп, большой улит, фифи, перевозчик, длиннопалый песочник, турухтан. Место обнаружения: оз. Байкал и устья байкальских рек, долина р. Селенги. 


\title{
Отряд Clinostomida Odening, 1963
}

\author{
Семейство Clinostomidae Luhe, 1901
}

2. Clinostomum complanatum (Rudolphi, 1819)

Хозяин: Аистообразные: серая цапля. Место обнаружения: устье р. Баргузин.

\section{Отряд Cyclocoelida Odening, 1961}

\section{Семейство Cyclocoelidae (Stossich, 1902)}

3. Cyclocoelum brasilianum Stossich, 1829

Хозяин: Ржанкообразные: чибис, щеголь, кулик-воробей, белохвостый песочник, краснозобик, турухтан. Место обнаружения: долина р. Селенги.

4. Cyclocoelum tringae Stossich, 1902

Хозяин: Ржанкообразные: чибис, большой веретенник, поручейник. Место обнаружения: оз. Байкал.

5. Cyclocoelum mutabile (Zeder, 1800)

Хозяин: Ржанкообразные: чибис, камнешарка, азиатский бекас, обыкновенный бекас, большой веретенник, поручейник, большой улит, черныш, фифи, перевозчик, турухтан, сизая чайка. Место обнаружения: долина р. Селенги.

6. Cyclocoelum microstomum Creplin, 1829

Хозяин: Гусеобразные: кряква, широконоска. Место обнаружения: оз. Байкал и устья байкальских рек, долина р. Баргузин.

7. Uvitellina adelphus (Johnston, 1916)

Хозяин: Ржанкообразные: чибис, галстучник, малый зуек, сизая чайка. Место обнаружения: оз. Байкал и устья байкальских рек.

8. Uvitellina vanelli (Rudolphi, 1819)

Хозяин: Ржанкообразные: чибис, большой веретенник, большой улит. Место обнаружения: оз. Байкал и устья байкальских рек, долина р. Селенги.

9. Typhlocoelum sisowi (Skrjabin, 1913)

Хозяин: Гусеобразные: кряква, хохлатая чернеть. Место обнаружения: оз. Байкал и устья байкальских рек.

10. Typhlocoelum cucumerinum (Rudolphi, 1809)

Хозяин: Ржанкообразные: монгольская чайка. Место обнаружения: оз. Байкал и устья байкальских рек.

11. Tracheophilus cymbium (Diesing, 1850)

Хозяин: Гусеобразные: кряква, хохлатая чернеть. Место обнаружения: оз. Байкал и устья байкальских рек.

\section{Отряд Fasciolida Skrjabin et Schulz, 1937}

\section{Семейство Echinostomatidae Dietz, 1909}

12. Echinostoma revolutum (Fröelich, 1802)

Хозяин: Гусеобразные: серая утка, кряква, черная кряква, красноголовый нырок. Поганкообразные: чомга, черношейная поганка. Ржанкообразные: кроншнепмалютка, мородунка, кулик-воробей, турухтан, сизая чайка, монгольская чайка, 
озерная чайка, речная крачка, белокрылая крачка. Место обнаружения: оз. Байкал и прилегающие участки рек, впадающих в него.

13. Echinostoma turkestanicum Kurova, 1926

Хозяин: Гусеобразные: красноголовый нырок. Место обнаружения: дельта p. Селенги, долина р. Баргузин.

14. Echinostoma paraulum Dietz, 1909

Хозяин: Гусеобразные: серая утка, кряква, хохлатая чернеть. Поганкообразные: чомга, красношейная поганка. Ржанкообразные: чибис, большой веретенник. Локализация: кишечник. Место обнаружения: оз. Байкал.

\section{Echinostoma stantschinskii Semenov, 1927}

Хозяин: Ржанкообразные: азиатский бекас, лесной дупель. Место обнаружения: разные районы Бурятии.

16. Echinoparyphium clerci Skrjabin, 1915

Хозяин: Гусеобразные: серая утка, шилохвость, красноголовый нырок, хохлатая чернеть. Поганкообразные: чомга, красношейная поганка. Ржанкообразные: чибис, поручейник, черныш, сизая чайка, монгольская чайка, озерная чайка, речная крачка, белокрылая крачка. Локализация: кишечник. Место обнаружения: оз. Байкал.

17. Echinoparyphium recurvatum (Linstow, 1873)

Хозяин: Гусеобразные: чирок-свистунок, шилохвость, красноголовый нырок, хохлатая чернеть, гоголь. Ржанкообразные: чибис, черныш, сизая чайка, монгольская чайка, озерная чайка, речная крачка, белокрылая крачка. Локализачия: кишечник. Место обнаружения: оз. Байкал.

18. Echinoparyphium aconiatum Dietz, 1909

Хозяин: Гусеобразные: серая утка, чирок-свистунок, хохлатая чернеть. Ржанкообразные: черныш, фифи, турухтан. Место обнаружения: оз. Байкал.

19. Echinoparyphium baculus (Diesing, 1850)

Хозяин: Гусеобразные: свиязь, кряква, чирок-трескунок, красноголовый нырок. Место обнаружения: оз. Байкал.

20. Echinoparyphium macrovitellatum Oschmarin, 1947

Хозяин: Пеликанообразные: большой баклан. Место обнаружения: дельта р. Селенги.

\section{Echinoparyphium nordiana Baschkirova, 1941}

Хозяин: Ржанкообразные: чибис, черныш, фифи. Место обнаружения: оз. Байкал.

22. Echinoparyphium politum Skrjabin, 1915

Хозяин: Ржанкообразные: азиатский бекас, обыкновенный бекас, черныш, фифи, мородунка, кулик-воробей, белохвостый песочник, турухтан. Место обнаружения: долина р. Селенги.

23. Longicollia echinata Bychowskaja-Pawlowskaja, 1953

Хозяин: Ржанкообразные: чибис, азиатский бекас, обыкновенный бекас, большой веретенник, поручейник. Место обнаружения: оз. Байкал и устья байкальских рек, долина р. Селенги.

24. Hypoderaeum conoideum (Bloch, 1782)

Хозяин: Гусеобразные: кряква. Место обнаружения: оз. Байкал и устья байкальских рек. 
25. Petasiger neocomense Fuhrmann, 1927

Хозяин: Поганкообразные: чомга. Место обнаружения: оз. Байкал.

26. Petasiger megacanthum (Kotlan, 1922)

Хозяин: Гусеобразные: широконоска, красноголовый нырок. Поганкообразные: чомга, красношейная поганка. Ржанкообразные: озерная чайка. Место обнаружения: оз. Байкал и устья байкальских рек.

27. Petasiger skrjabini Baschkirova, 1941

Хозяин: Поганкообразные: чомга. Место обнаружения: оз. Байкал.

28. Petasiger aeratus Oschmarin, 1947

Хозяин: Аистообразные: серая цапля. Поганкообразные: большая поганка. Место обнаружения: оз. Байкал.

29. Petasiger spasskyi Oschmarin, 1947

Хозяин: Аистообразные: серая цапля. Место обнаружения: устье р. Баргузин.

\section{Семейство Echinochasmidae (Odhner, 1911)}

30. Mesorchis pseudoechinatus (Olsson, 1876)

Хозяин: Ржанкообразные: монгольская чайка. Место обнаружения: дельта р. Селенги.

31. Echinochasmus spinulosus (Rud., 1809)

Хозяин: Поганкообразные: чомга. Место обнаружения: оз. Байкал.

32. Echinochasmus coaxatus Dietz, 1909

Хозяин: Поганкообразные: большая поганка. Место обнаружения: оз. Байкал.

\section{Семейство Parorchidae Lal, 1936}

33. Parorchis acanthus (Nicoll, 1906)

Хозяин: Ржанкообразные: монгольская чайка. Место обнаружения: оз. Байкал.

34. Parorchis gedoelsti (Skrjabin, 1924)

Хозяин: Ржанкообразные: камнешарка, большой улит, сибирский пепельный улит. Место обнаружения: оз. Байкал.

35. Parorchis sp.

Хозяин: Ржанкообразные: монгольская чайка. Место обнаружения: оз. Байкал.

\section{Семейство Philophthalmidae (Looss, 1899)}

\section{Philophthalmus lucipetus (Rudolphi, 1819)}

Хозяин: Ржанкообразные: сизая чайка, монгольская чайка, озерная чайка. Место обнаружения: оз. Байкал и устья байкальских рек.

37. Philophthalmus palpebrarum Looss, 1899

Хозяин: Ржанкообразные: речная крачка, белокрылая крачка. Место обнаружения: оз. Байкал и устья байкальских рек.

38. Philophthalmus skrjabini Efimov, 1937

Хозяин: Ржанкообразные: монгольская чайка. Место обнаружения: оз. Байкал.

39. Pygorchis alakolensis Jatkanbaeva, 1967

Хозяин: Ржанкообразные: сизая чайка, белокрылая крачка. Место обнаружения: оз. Байкал и устья байкальских рек. 
Ц. З. Доржиев, Е. Н. Бадмаева, Ж. Н. Дугаров. Гельминты водно-болотных птиц Байкальской Сибири: таксономическое разнообразие и распределение по хозяевам

\section{Семейство Psilostomidae Odhner, 1913}

40. Psilochasmus oxyurus (Creplin, 1825)

Хозяин: Гусеобразные: кряква. Место обнаружения: оз. Байкал и устья байкальских рек.

41. Psilotrema simillimum (Mühling, 1898)

Хозяин: Гусеобразные: чирок-свистунок. Ржанкообразные: сизая чайка, речная крачка. Место обнаружения: оз. Байкал и устья байкальских рек.

42. Psilotrema mediopora Oshmarin, 1963

Хозяин: Гусеобразные: чирок-свистунок. Место обнаружения: оз. Байкал и устья байкальских рек.

43. Psilotrema spiculigerum (Mühling, 1898)

Хозяин: Гусеобразные: чирок-свистунок. Место обнаружения: оз. Байкал и устья байкальских рек.

44. Sphaeridiotrema globulus (Rudolphi, 1819)

Хозяин: Гусеобразные: чирок-свистунок, красноголовый нырок. Поганкообразные: чомга. Ржанкообразные: речная крачка. Место обнаружения: оз. Байкал и устья байкальских рек.

\section{Отряд Notocotylida Skrjabin et Schulz, 1933}

Семейство Notocotylidae Luhe, 1909

\section{Notocotylus attenuatus (Rudolphi, 1809)}

Хозяин: Гусеобразные: свиязь, серая утка, чирок-свистунок, кряква, широконоска, красноголовый нырок, хохлатая чернеть, луток. Поганкообразные: чомга. Журавлеобразные: лысуха. Ржанкообразные: сизая чайка. Место обнаружения: оз. Байкал и устья байкальских рек.

46. Notocotylus linearis (Rudolphi, 1819)

Хозяин: Гусеобразные: свиязь, серая утка, кряква, красноголовый нырок. Ржанкообразные: чибис, черныш, фифи, мородунка, сизая чайка. Место обнаружения: о3. Байкал и устья байкальских рек.

47. Notocotylus gibbus (Mehlis, 1846)

Хозяин: Гусеобразные: луток. Журавлеобразные: лысуха. Место обнаружения: оз. Байкал.

48. Catatropis verrucosa (Fröhlich, 1789)

Хозяин: Гусеобразные: кряква, широконоска. Место обнаружения: оз. Байкал.

\section{Отряд Plagiorchida La Rue, 1957}

\section{Семейство Plagiorchiidae Luhe, 1901}

49. Plagiorchis elegans (Rudolphi, 1802)

Хозяин: Гусеобразные: серая утка, кряква, хохлатая чернеть. Ржанкообразные: сизая чайка, монгольская чайка, озерная чайка, речная и белокрылая крачки. Место обнаружения: оз. Байкал, оз. Гусиное, реки бассейна Байкала. 


\section{Plagiorchis laricola Skrjabin, 1924}

Хозяин: белокрылая крачка. Поганкообразные: чомга. Ржанкообразные: сизая чайка, монгольская чайка, озерная чайка, малая чайка, чеграва, речная крачка, белокрылая крачка. Место обнаружения: оз. Байкал и устья байкальских рек.

51. Plagiorchis multiglandularis Semenov, 1927

Хозяин: Ржанкообразные: сизая чайка, монгольская чайка, озерная чайка, речная крачка. Место обнаружения: оз. Байкал и устья байкальских рек.

52. Plagiorchis brauni Massino, 1927

Хозяин: Ржанкообразные: речная крачка. Место обнаружения: оз. Гусиное.

53. Plagiorchis arcuatus Strom, 1924

Хозяин: Гусеобразные: чирок-свистунок, кряква. Ржанкообразные: сизая чайка, монгольская чайка, речная крачка, белокрылая крачка. Место обнаружения: оз. Байкал и устья байкальских рек, оз. Гусиное.

54. Plagiorchis maculosus (Rudolphi, 1802)

Хозяин: Гусеобразные: красноголовый нырок. Ржанкообразные: сизая чайка, монгольская чайка. Место обнаружения: оз. Байкал и устья байкальских рек.

55. Plagiorchis vitellatus (Linstow, 1875)

Хозяин: Ржанкообразные: черныш, фифи, сибирский пепельный улит, перевозчик, мородунка, круглоносый плавунчик, кулик-воробей, турухтан. Место обнаружения: оз. Байкал и устья байкальских рек, долина р. Селенги.

56. Plagiorchis nyrocae Ryjikov et Timofeeva, 1962

Хозяин: Гусеобразные: красноголовый нырок. Ржанкообразные: галстучник, черныш, фифи, сибирский пепельный улит, перевозчик, мородунка, круглоносый плавунчик, кулик-воробей. Место обнаружения: оз. Байкал и устья байкальских рек.

57. Plagiorchis nanus (Rudolphi, 1802)

Хозяин: Ржанкообразные: галстучник, малый зуек, азиатский бекас, обыкновенный бекас, малый веретенник, кроншнеп-малютка, большой кроншнеп, щеголь, большой улит, черныш, фифи, перевозчик, мородунка, круглоносый плавунчик, длиннопалый песочник, краснозобик, острохвостый песочник, турухтан. Место обнаружения: оз. Байкал и устья байкальских рек, долина р. Селенги.

58. Plagiorchis uhlwormii Massino, 1927

Хозяин: Ржанкообразные: большой веретенник, кроншнеп-малютка, большой кроншнеп, перевозчик, кулик-воробей. Место обнаружения: дельта и долина р. Селенги.

\section{Семейство Prosthogonimidae Nicoll, 1924}

\section{Prosthogonimus cuneatus Rudolphi, 1809}

Хозяин: Гусеобразные: кряква. Ржанкообразные: обыкновенный бекас, большой веретенник, кроншнеп-малютка, большой кроншнеп, большой улит, черныш, перевозчик, кулик-воробей, турухтан. Поганкообразные: чомга. Место обнаружения: оз. Байкал и устья байкальских рек, Цайдамские озера.

60. Prosthogonimus sudarikowi Oschmarin, 1946

Хозяин: Гусеобразные: красноголовый нырок. Место обнаружения: оз. Байкал и устья байкальских рек.

61. Prosthogonimus ovatus Rudolphi, 1803

Хозяин: Гусеобразные: кряква. Поганкообразные: чомга, черношейная поганка. 
Ржанкообразные: чибис, черныш, фифи, сизая чайка, монгольская чайка, озерная чайка, речная крачка. Место обнаружения: оз. Байкал и устья байкальских рек.

62. Prosthogonimus anatinus Markov, 1902

Хозяин: Гусеобразные: луток. Место обнаружения: оз. Байкал и устья байкальских рек.

63. Schistogonimus rarus (Braun, 1901)

Хозяин: Ржанкообразные: большой кроншнеп. Место обнаружения: долина р. Селенги.

\section{Семейство Dicrocoeliidae (Looss, 1899)}

64. Dicrocoelium anatis (Belogurov et Leonov, 1963)

Хозяин: Ржанкообразные: сизая чайка. Место обнаружения: оз. Байкал, р. Верхняя Ангара.

65. Lyperosomum lari Travassos, 1917

Хозяин: Ржанкообразные: монгольская чайка. Место обнаружения: оз. Байкал.

\section{Семейство Eucotylidae Skrjabin, 1924}

\section{Tanaisia fedtschenkoi Skrjabin, 1924}

Хозяин: Ржанкообразные: галстучник, малый зуек, азиатский бекас, обыкновенный бекас, большой улит, черныш, фифи, сибирский пепельный улит, сизая чайка, монгольская чайка. Место обнаружения: оз. Байкал, оз. Гусиное.

\section{Отряд Schistosomatida Skrjabin et Schulz, 1937 \\ Семейство Bilharziellidae (Price, 1929)}

\section{Bilharziella polonica (Kowalewski, 1895)}

Хозяин: Гусеобразные: кряква. Поганкообразные: чомга. Ржанкообразные: сизая чайка, монгольская чайка, речная крачка, белокрылая крачка. Место обнаружения: оз. Байкал и устья байкальских рек.

68. Dendritobilharzia pulverulenta (Braun, 1901)

Хозяин: Гусеобразные: кряква. Место обнаружения: оз. Байкал и устья байкальских рек.

69. Ornithobilharzia canaliculata (Rudolphi, 1819)

Хозяин: Ржанкообразные: сизая чайка, озерная чайка. Место обнаружения: оз. Байкал и устья байкальских рек.

\section{Отряд Opisthorchida La Rue, 1957}

\section{Семейство Opisthorchidae (Looss, 1899)}

70. Opisthorchis simulans (Looss, 1896)

Хозяин: Гусеобразные: хохлатая чернеть. Место обнаружения: оз. Байкал и устья байкальских рек. 
71. Erschoviorchis lintoni (Gower, 1939)

Хозяин: Ржанкообразные: сизая чайка, монгольская чайка, озерная чайка, речная крачка, белокрылая крачка. Место обнаружения: оз. Байкал и устья байкальских рек.

72. Metorchis xanthosomus (Creplin, 1846)

Хозяин: Ржанкообразные: монгольская чайка. Место обнаружения: оз. Байкал.

73. Metametorchis butoridi (Oschmarin, 1963)

Хозяин: Ржанкообразные: монгольская чайка. Место обнаружения: оз. Байкал и устья байкальских рек.

\section{Семейство Pachytrematidae (Railliet, 1919)}

74. Pachytrema paniceum Bringmann, 1942

Хозяин: Ржанкообразные: сизая чайка, монгольская чайка, озерная чайка. Место обнаружения: оз. Байкал и устья байкальских рек.

\section{Семейство Heterophyidae Odhner, 1914}

75. Heterophyes heterophyes (Siebold, 1852)

Хозяин: Поганкообразные: большая поганка. Ржанкообразные: сизая чайка, монгольская чайка, чеграва. Место обнаружения: оз. Байкал и устья байкальских рек.

\section{Семейство Galactosomatidae Morosov, 1950}

76. Knipowitschetrema ussuriensis (Oschmarin, 1963)

Хозяин: Ржанкообразные: чеграва. Место обнаружения: оз. Байкал и устья байкальских рек.

77. Stictodora lari Yamaguti, 1939

Хозяин: Ржанкообразные: монгольская чайка. Место обнаружения: оз. Байкал и устья байкальских рек.

78. Stictodora sawakinensis Looss, 1899

Хозяин: Ржанкообразные: сизая чайка, монгольская чайка, озерная чайка, речная крачка, белокрылая крачка. Место обнаружения: оз. Байкал и устья байкальских рек.

\section{Семейство Tetracladiidae (Yamaguti, 1958)}

79. Tetracladium sterna Kulachkowa, 1954

Хозяин: Ржанкообразные: сизая чайка, монгольская чайка, чеграва, речная крачка, белокрылая крачка. Место обнаружения: оз. Байкал и устья байкальских рек.

\section{Отряд Renicolida La Rue, 1957}

\section{Семейство Renicolidae Dollfus, 1939}

80. Renicola lari Timon-David, 1933

Хозяин: Ржанкообразные: сизая чайка, монгольская чайка. Место обнаружения: оз. Байкал. 
Ц. 3. Доржсиев, Е. Н. Бадмаева, Ж. Н. Дугаров. Гельминты водно-болотных птиц Байкальской Сибири: таксономическое разнообразие и распределение по хозяевам

81. Renicola pinguis (Mehlis in Creplin, 1846)

Хозяин: Поганкообразные: чомга. Место обнаружения: оз. Байкал.

\section{Отряд Strigeidida (La Rue, 1926)}

\section{Семейство Strigeidae Railliet, 1919}

\section{Apatemon gracilis (Rudolphi, 1819)}

Хозяин: Гусеобразные: серая утка, чирок-свистунок, кряква, чирок-трескунок, красноголовый нырок, хохлатая чернеть, гоголь, луток. Журавлеобразные: лысуха. Ржанкообразные: монгольская чайка. Место обнаружения: оз. Байкал и устья байкальских рек.

83. Apatemon fuligulae Yamaguti, 1933

Хозяин: Гусеобразные: длинноносый крохаль. Место обнаружения: оз. Байкал и устья байкальских рек.

84. Apharyngostrigea cornu (Zeder, 1800)

Хозяин: Аистообразные: серая цапля. Поганкообразные: большая поганка. Место обнаружения: оз. Байкал и устья байкальских рек.

85. Cotylurus cornutus (Rudolphi, 1808)

Хозяин: Гусеобразные: свиязь, серая утка, чирок-свистунок, кряква, черная кряква, широконоска, красноголовый нырок, хохлатая чернеть, луток. Поганкообразные: чомга. Ржанкообразные: чибис, фифи, кулик-воробей. Место обнаружения: оз. Байкал и устья байкальских рек.

86. Cotylurus erraticus (Rudolphi, 1809)

Хозяин: Поганкообразные: чомга, черношейная поганка, красношейная поганка. Место обнаружения: оз. Байкал и устья байкальских рек.

87. Cotylurus pileatus (Rudolphi, 1802)

Хозяин: Ржанкообразные: сизая чайка, монгольская чайка, озерная чайка, белокрылая крачка, речная крачка. Место обнаружения: оз. Байкал и устья байкальских рек.

88. Cotylurus platycephalus (Creplin, 1825)

Хозяин: Ржанкообразные: сизая чайка, монгольская чайка, озерная чайка, речная крачка, белокрылая крачка. Место обнаружения: оз. Байкал и устья байкальских рек.

89. Ophiosoma patagiatum (Creplin, 1846)

Хозяин: Поганкообразные: чомга. Место обнаружения: оз. Байкал.

90. Parastrigea anati Bychowskaja-Pawlowskaja et Zhukov, 1953

Хозяин: Гусеобразные: кряква. Место обнаружения: оз. Байкал и устья байкальских рек.

\section{Семейство Diplostomidae (Poirier, 1886)}

\section{Diplostomum chromatophorum (Brown, 1931)}

Хозяин: Ржанкообразные: сизая чайка, монгольская чайка, озерная чайка, речная крачка, белокрылая крачка. Место обнаружения: оз. Байкал и устья байкальских рек. 
92. Diplostomum gasterostei Williams, 1966

Хозяин: Ржанкообразные: черныш. Место обнаружения: долина р. Селенги.

93. Diplostomum rutili Razmashkin, 1969

Хозяин: Ржанкообразные: сизая чайка, монгольская чайка, озерная чайка, речная крачка, белокрылая крачка. Место обнаружения: оз. Байкал и устья байкальских рек.

94. Diplostomum gavium (Guberlet, 1922)

Хозяин: Гусеобразные: кряква. Поганкообразные: чомга, черношейная поганка. Место обнаружения: оз. Байкал и устья байкальских рек.

95. Diplostomum helveticum (Dubois, 1929)

Хозяин: Ржанкообразные: сизая чайка, монгольская чайка, озерная чайка, малая чайка, речная крачка. Место обнаружения: оз. Байкал и устья байкальских рек.

96. Diplostomum mergi Dubois, 1932

Хозяин: Гусеобразные: луток, большой крохаль. Ржанкообразные: черныш, перевозчик. Место обнаружения: оз. Байкал и устья байкальских рек.

97. Diplostomum volvens Nordmann, 1832

Хозяин: Ржанкообразные: сизая чайка, монгольская чайка, озерная чайка. Место обнаружения: оз. Байкал и устья байкальских рек.

98. Diplostomum pusillum (Dubois, 1928)

Хозяин: Гусеобразные: кряква, луток. Место обнаружения: оз. Байкал и устья байкальских рек.

99. Diplostomum spathaceum (Rudolphi, 1819)

Хозяин: Ржанкообразные: сизая чайка, монгольская чайка, озерная чайка, речная крачка, белокрылая крачка. Место обнаружения: оз. Байкал и устья байкальских рек.

100. Tylodelphys clavata (Nordmann, 1832)

Хозяин: Поганкообразные: чомга. Место обнаружения: оз. Байкал и устья байкальских рек.

101. Tylodelphys conifera (Mehlis, 1846) Dubois, 1937

Хозяин: Поганкообразные: чомга. Место обнаружения: оз. Байкал и устья байкальских рек.

\section{Семейство Cyathocotylidae Poche, 1925}

\section{Holostephanus dubius (Szidat, 1936)}

Хозяин: Ржанкообразные: озерная чайка. Место обнаружения: оз. Байкал и устья байкальских рек.

103. Cyathocotyle prussica Mühling, 1896

Хозяин: Гусеобразные: кряква, красноголовый нырок. Место обнаружения: оз. Байкал и устья байкальских рек.

104. Cyathocotyle orientalis Faust, 1922

Хозяин: Ржанкообразные: сизая чайка, монгольская чайка. Место обнаружения: оз. Байкал и устья байкальских рек.

105. Duboisia teganuma (Ishii, 1935)

Хозяин: Поганкообразные: чомга. Место обнаружения: оз. Байкал. 
Ц. З. Доржиев, Е. Н. Бадмаева, Ж. Н. Дугаров. Гельминты водно-болотных птиц Байкальской Сибири: таксономическое разнообразие и распределение по хозяевам

\section{Семейство Orchipedidae (Skrjabin, 1913)}

106. Orchipedium tracheicola Braun, 1901

Хозяин: Ржанкообразные: сизая чайка, монгольская чайка, речная крачка, белокрылая крачка. Место обнаружения: оз. Байкал и устья байкальских рек, оз. Гусиное.

КЛАСС НЕМАТОДА - NЕМАТОDА

\section{Отряд Trichocephalida Skrjabin et Schulz, 1928}

\section{Семейство Capillariidae Neveu-Lemaire, 1936}

\section{Eucoleus trilobus (Linstow, 1875)}

Хозяин: Ржанкообразные: галстучник, малый зуек, перевозчик, кулик-воробей. Место обнаружения: оз. Байкал и устья байкальских рек, долина р. Селенги.

2. Thominx contorta (Creplin, 1839)

Хозяин: Гусеобразные: чирок-свистунок. Ржанкообразные: поручейник, большой улит, фифи, сизая чайка, озерная чайка. Место обнаружения: оз. Байкал и устья байкальских рек, долина р. Селенги.

\section{Thominx limicolae Mamaev, 1959}

Хозяин: Ржанкообразные: бурокрылая ржанка, азиатский бекас, обыкновенный бекас, вальдшнеп, кроншнеп-малютка, перевозчик, мородунка. Место обнаружения: оз. Байкал и устья байкальских рек, долина р. Селенги.

4. Thominx anatis (Schrank, 1790)

Хозяин: Гусеобразные: чирок-свистунок. Место обнаружения: оз. Байкал и устья байкальских рек.

\section{Отряд Ascaridida Skrjabin et Schulz, 1940}

\section{Семейство Anisakidae Skrjabin et Karochin, 1945}

\section{Controcaecum spiculigerum (Rud. 1809)}

Хозяин: Пеликанообразные: большой баклан. Место обнаружения: оз. Байкал.

\section{Отряд Dioctophymida Skrjabin, 1927}

\section{Семейство Dioctophymidae Railliet, 1915}

\section{Eustrongylides mergorum (Rudolphi, 1809)}

Хозяин: Гусеобразные: большой крохаль. Место обнаружения: оз. Байкал и устья байкальских рек. 


\section{Отряд Spirurida Chitwood, 1933}

\section{Семейство Tetrameridae Travassos, 1914}

\section{Tetrameres dubia Travassos, $\mathbf{1 9 1 7}$}

Хозяин: Ржанкообразные: галстучник, вальдшнеп, азиатский бекас, щеголь, большой улит, черныш, фифи, сибирский пепельный улит, мородунка, кулик-воробей, краснозобик, острохвостый песочник. Место обнаружения: оз. Байкал и устья байкальских рек, долина р. Селенги.

\section{Tetrameres fissispina (Diesing, 1861)}

Хозяин: Гусеобразные: серая утка, чирок-свистунок, кряква. Ржанкообразные: чибис, сизая чайка, монгольская чайка, озерная чайка. Место обнаружения: оз. Байкал и устья байкальских рек.

\section{Tetrameres numenii Mamaev, 1959}

Хозяин: Поганкообразные: чомга, черношейная поганка, красношейная поганка. Ржанкообразные: большой кроншнеп, кроншнеп-малютка, сизая чайка, монгольская чайка, озерная чайка. Место обнаружения: оз. Байкал и устья байкальских рек.

10. Tetrameres uxorious Mamaev, 1959

Хозяин: Ржанкообразные: перевозчик. Место обнаружения: оз. Байкал и устья байкальских рек, долина р. Селенги.

\section{Tetrameres araliensis Efimov \& Rijova, 1939}

Хозяин: Ржанкообразные: вальдшнеп, азиатский бекас, обыкновенный бекас. Место обнаружения: оз. Байкал и устья байкальских рек, долина р. Селенги.

12. Tetrameres ryjikowi Chuan, 1961

Хозяин: Гусеобразные: чирок-свистунок. Место обнаружения: оз. Байкал и устья байкальских рек.

13. Tetrameres skrjabini Panowa, 1926

Хозяин: Поганкообразные: чомга, черношейная поганка, красношейная поганка. Ржанкообразные: сизая чайка, монгольская чайка, озерная чайка. Место обнаружения: оз. Байкал и устья байкальских рек.

\section{Семейство Acuariidae Seurat, 1913}

\section{Cosmocephalus capellae Yamaguti, 1935}

Хозяин: Ржанкообразные: щеголь, поручейник. Место обнаружения: оз. Байкал и устья байкальских рек, долина р. Селенги.

15. Cosmocephalus obvelatus (Creplin, 1825)

Хозяин: Ржанкообразные: азиатский бекасовидный веретенник, большой веретенник, щеголь, большой улит, фифи, сибирский пепельный улит. Место обнаружения: оз. Байкал и устья байкальских рек, долина р. Селенги.

16. Echinuria uncinata (Rudolphi, 1819)

Хозяин: Гусеобразные: огарь. Место обнаружения: оз. Гусиноозерск.

17. Schistorophus cornutus Sobolev, 1943

Хозяин: Ржанкообразные: большой улит, фифи, мородунка, сизая чайка, монгольская чайка, озерная чайка. Место обнаружения: оз. Байкал и устья байкальских рек. 


\section{Streptocara crassicauda (Creplin, 1829)}

Хозяин: Гагарообразные: чернозобая гагара, краснозобая гагара. Поганкообразные: чомга. Ржанкообразные: большой улит, мородунка, сизая чайка, монгольская чайка, озерная чайка. Место обнаружения: оз. Байкал и устья байкальских рек.

\section{Семейство Desmidocercidae Cram, 1927}

\section{Desmidocercella numidica Seurat, 1920}

Хозяин: Аистообразные: серая цапля. Место обнаружения: дельта р. Селенги.

\section{Семейство Anisakidae Skrjabin et Karokhin, 1945}

\section{Porrocaecum crassum (Deslongchamps, 1824)}

Хозяин: Гусеобразные: серая утка, чирок-свистунок, кряква, широконоска, гоголь, луток. Журавлеобразные: лысуха. Место обнаружения: оз. Байкал и устья байкальских рек.

21. Porrocaecum ensicaudatum (Zeder, 1800)

Хозяин: Ржанкообразные: чибис, перевозчик. Место обнаружения: оз. Байкал и устья байкальских рек, долина р. Селенги.

22. Porrocaecum semiteres (Zeder 1800)

Хозяин: Ржанкообразные: чибис, бурокрылая ржанка, галстучник, вальдшнеп, азиатский бекас, обыкновенный бекас, фифи, перевозчик, мородунка, куликворобей, длиннопалый песочник. Место обнаружения: оз. Байкал и устья байкальских рек, долина р. Селенги.

23. Contracaecum spiculigerum (Rudolphi, 1809)

Хозяин: Гагарообразные: краснозобая гагара, чернозобая гагара. Пеликанообразные: большой баклан. Поганкообразные: чомга, красношейная поганка. Ржанкообразные: чибис, большой улит, фифи, сизая чайка, озерная чайка, монгольская чайка. Место обнаружения: оз. Байкал и устья байкальских рек.

24. Contracaecum microcephalum (Rudolphi, 1819)

Хозяин: Ржанкообразные: озерная чайка. Место обнаружения: оз. Байкал и устья байкальских рек.

25. Contracaecum spasskyi Mozgovoy, 1950

Хозяин: Ржанкообразные: длиннопалый песочник, краснозобик. Место обнаружения: оз. Байкал и устья байкальских рек, долина р. Селенги.

\section{Семейство Aproctidae (Yorke et Maplestone, 1926)}

\section{Aprocta turgida Stossich, 1902}

Хозяин: Ржанкообразные: монгольская чайка. Место обнаружения: оз. Байкал и устья байкальских рек.

\section{Отряд Rhabditida (Oerley, 1880)}

\section{Семейство Amidostomatidae Baylis et Daubney, 1926}

27. Amidostomum acutum (Lundahl, 1848)

Хозяин: Гусеобразные: кряква. Место обнаружения: оз. Байкал и устья байкальских рек. 
28. Amidostomum anseris (Zeder, 1800)

Хозяин: Гусеобразные: серая утка, чирок-свистунок, красноголовый нырок, хохлатая чернеть. Место обнаружения: оз. Байкал и устья байкальских рек.

29. Amidostomum henryi Skrjabin, 1915

Хозяин: Ржанкообразные: чибис. Место обнаружения: дельта р. Селенги.

\section{Семейство Syngamidae Leiper, 1912}

\section{Syngamus anterogonimus Ryjikov, 1949}

Хозяин: Ржанкообразные: большой улит, фифи, кулик-воробей, озерная чайка. Место обнаружения: оз. Байкал и устья байкальских рек.

31. Syngamus gibbocephalus Ryjikov, 1949

Хозяин: Ржанкообразные: вальдшнеп, азиатский бекас, обыкновенный бекас. Место обнаружения: оз. Байкал и устья байкальских рек, долина р. Селенги.

32. Syngamus palustris Ryjikov, 1949

Хозяин: Ржанкообразные: турухтан. Место обнаружения: оз. Байкал и устья байкальских рек.

33. Cyathostoma bronchialis (Mühlig, 1884)

Хозяин: Ржанкообразные: озерная чайка. Место обнаружения: оз. Байкал и устья байкальских рек.

\section{Семейство Trichostrongylidae Leiper, 1912}

\section{Epomidiostomum anatinum Skrjabin, 1915}

Хозяин: Гусеобразные: свиязь, чирок-свистунок, кряква, красноголовый нырок. Место обнаружения: оз. Байкал и устья байкальских рек.

\section{Epomidiostomum uncinatum (Lundahl, 1848)}

Хозяин: Гусеобразные: кряква. Поганкообразные: чомга. Место обнаружения: оз. Байкал и устья байкальских рек.

\section{Семейство Strongylidae Baird, 1853}

36. Strongyloides turkmenica Kurtieva, 1953

Хозяин: Ржанкообразные: камнешарка, большой улит, черныш, фифи, мородунка, кулик-воробей. Место обнаружения: оз. Байкал и устья байкальских рек, долина р. Селенги.

КЛАСС СКРЕБНИ - PALAEACANTHOCEPHALA MEYER, 1931

\section{Отряд Polymorphida Petrotschenko, 1956}

\section{Семейство Polymorphidae Mayer, 1931}

\section{Polymorphus minutus (Goeze, 1782)}

Хозяин: Гусеобразные: свиязь, серая утка, чирок-свистунок, кряква, черная кряква, широконоска, красноголовый нырок, хохлатая чернеть, горбоносый турпан, 
гоголь, луток. Поганкообразные: чомга, красношейная поганка. Журавлеобразные: лысуха. Ржанкообразные: сизая чайка, монгольская чайка, озерная чайка, малая чайка, речная крачка, белокрылая крачка. Место обнаружения: оз. Байкал и дельта р. Селенги.

\section{Polymorphus acutis Van Cleave and Starrett, 1940}

Хозяин: Гусеобразные: горбоносый турпан, гоголь, кряква. Журавлеобразные: лысуха. Ржанкообразные: сизая чайка. Место обнаружения: оз. Байкал и дельта р. Селенги.

\section{Polymorphus magnus Skrjabin, 1913}

Хозяин: Гусеобразные: серая утка, чирок-свистунок, кряква, шилохвость, широконоска, красноголовый нырок, хохлатая чернеть, гоголь, луток, большой крохаль. Поганкообразные: чомга. Журавлеобразные: лысуха. Ржанкообразные: сизая чайка, монгольская чайка, озерная чайка, речная крачка, белокрылая крачка. Место обнаружения: оз. Байкал и устья байкальских рек.

\section{Corynosoma strumosum (Rudolphi, 1802)}

Хозяин: Ржанкообразные: сизая чайка, монгольская чайка, озерная чайка. Место обнаружения: оз. Байкал и дельта р. Селенги.

\section{Filicollis anatis (Schrank, 1788)}

Хозяин: Гусеобразные: серая утка, чирок-свистунок, кряква, широконоска, красноголовый нырок, хохлатая чернеть. Журавлеобразные: лысуха. Место обнаружения: оз. Байкал и устья байкальских рек.

Итак, приведенный нами таксономический список гельминтов водно-болотных птиц Байкальской Сибири позволяет обратить внимание на некоторые особенности. Еще раз отмечаем, что паразиты водно-болотных птиц региона изучены еще недостаточно, вскрытию подвергалось менее половины видового состава. Причем достаточно большой материал (более 20 вскрытых особей) имеется по отряду гусеобразных - серой утке, чирку-свистунку, крякве, широконоске, красноголовой и хохлатой чернетям и большому крохалю, по поганкообразным чомге, журавлеобразным - лысухе, ржанкообразным - чибису, большому веретеннику, поручейнику, фифи, сизая, монгольская и озерная чайки. Это всего 16 видов, или $10,7 \%$ видового состава семи основных отрядов гидрофильных птиц Байкальской Сибири. Некоторые обычные и даже многочисленные виды птиц остались слабоизученными, а более $50 \%$ видов оказались вообще не исследованными. Такое обстоятельство не позволяет установить общую картину состава гельминтофауны этой группы птиц, за исключением отдельных видов.

Всего в настоящее время выявлено у водно-болотных птиц Байкальской Сибири 243 вида гельминтов из 47 семейств, 113 родов (табл. 2). Наиболее богатым в таксономическом отношении оказался класс трематод - 107 видов, распределенных по 10 отрядам, 14 семействам и 50 родам. Далее идет класс цестоды, который представлен 94 видами из 3 отрядов, 9 семейств и 42 родов. Нематодов выявлено немного - 36 видов из 5 отрядов, 12 семейств и 18 родов. И еще меньше скребней -5 видов, представляющих один отряд, одно семейство и три рода. 
Количественная характеристика таксономического состава гельминтов водно-болотных птиц Байкальской Сибири

\begin{tabular}{|c|c|c|c|}
\hline \multicolumn{4}{|c|}{ Класс ЦЕСТОДА - СЕSTODА } \\
\hline \multirow{2}{*}{ Отряды } & \multirow{2}{*}{ Семейства } & \multicolumn{2}{|c|}{ Число } \\
\hline & & родов & видов \\
\hline \multirow[t]{2}{*}{ Pseudophyllidea } & Diphyllobothriidae & 1 & 2 \\
\hline & Ligulidae & 3 & 5 \\
\hline Tetraphyllidea & Tetrabothriidae & 1 & 1 \\
\hline \multirow[t]{6}{*}{ Cyclophyllidea } & Dilepididae & 10 & 16 \\
\hline & Choanotaeniidae & 6 & 16 \\
\hline & Hymenolepididae & 18 & 51 \\
\hline & Amabiliidae & 1 & 1 \\
\hline & Progynotaeniidae & 1 & 1 \\
\hline & Paruterinidae & 1 & 1 \\
\hline Число таксонов в классе: & 9 & 42 & 94 \\
\hline \multicolumn{4}{|c|}{ Класс ТРЕМАТОДА - ТRЕМАТОDА } \\
\hline Brachylaimida & Leucochloridiidae & 1 & 1 \\
\hline Clinostomida & Clinostomidae & 1 & 1 \\
\hline Cyclocoelida & Cyclocoelidae & 3 & 9 \\
\hline \multirow[t]{5}{*}{ Fasciolida } & Echinostomatidae & 5 & 18 \\
\hline & Echinochasmidae & 2 & 3 \\
\hline & Parorchidae & 1 & 3 \\
\hline & Philophthalmidae & 2 & 4 \\
\hline & Psilostomidae & 3 & 5 \\
\hline Notocotylida & Notocotylidae & 2 & 4 \\
\hline \multirow[t]{4}{*}{ Plagiorchida } & Plagiorchiidae & 1 & 10 \\
\hline & Prosthogonimidae & 2 & 6 \\
\hline & Dicrocoeliidae & 2 & 2 \\
\hline & Eucotylidae & 1 & 1 \\
\hline Schistosomatida & Bilharziellidae & 3 & 3 \\
\hline \multirow[t]{5}{*}{ Opisthorchida } & Opisthorchidae & 4 & 4 \\
\hline & Pachytrematidae & 1 & 1 \\
\hline & Heterophyidae & 1 & 1 \\
\hline & Galactosomatidae & 2 & 3 \\
\hline & Tetracladiidae & 1 & 1 \\
\hline Renicolida & Renicolidae & 1 & 2 \\
\hline \multirow[t]{4}{*}{ Strigeidida } & Strigeidae & 5 & 9 \\
\hline & Diplostomidae & 2 & 11 \\
\hline & Cyathocotylidae & 3 & 4 \\
\hline & Orchipedidae & 1 & 1 \\
\hline Число таксонов в классе: & 24 & 50 & 107 \\
\hline
\end{tabular}


Ц. 3. Доржиев, Е. Н. Бадмаева, Ж. Н. Дугаров. Гельминты водно-болотных птиц Байкальской Сибири: таксономическое разнообразие и распределение по хозяевам

\begin{tabular}{|c|c|c|c|}
\hline \multicolumn{4}{|c|}{ Класс НЕМАТОДА - NЕМАТОDА } \\
\hline Trichocephalida & Capillariidae & 2 & 4 \\
\hline Dioctophymida & Dioctophymidae & 1 & 1 \\
\hline \multirow[t]{5}{*}{ Spirurida } & Tetrameridae & 1 & 7 \\
\hline & Acuariidae & 4 & 5 \\
\hline & Desmidocercidae & 1 & 1 \\
\hline & Anisakidae & 2 & 6 \\
\hline & Aproctidae & 1 & 1 \\
\hline \multirow[t]{4}{*}{ Rhabditida } & Amidostomidae & 1 & 3 \\
\hline & Syngamidae & 2 & 4 \\
\hline & Trichostrongylidae & 1 & 2 \\
\hline & Strongyloididae & 1 & 1 \\
\hline Ascaridida & Anisakidae & 1 & 1 \\
\hline Число таксонов в классе: & 12 & 18 & 36 \\
\hline \multicolumn{4}{|c|}{ КЛасс СКРЕБНИ - PALAЕАСАNТНОСЕРНАLA } \\
\hline Polymorphida & Polymorphidae & 3 & 5 \\
\hline Число таксонов в классе: & 1 & 3 & 5 \\
\hline Общее число таксонов: & 47 & 113 & 243 \\
\hline
\end{tabular}

Если рассмотреть по отрядам, то складывается такая картина. Из цестод наиболее богат отряд Cyclophyllidea (86 видов), из трематод - Fasciolida (33), Plagiorchida (19), Strigeidida (25). Обращают внимание и некоторые семейства, богатые в видовом отношении: из цестод - Hymenolepididae (51 вид), Dilepididae и Choanotaeniidae (по 16 видов); из трематод — Echinostomatidae (18), Plagiorchiidae (10), Diplostomidae (11).

Выделены отдельные относительно богатые рода (более 5 видов), из цестод таковых 4 рода, из трематод - 3, из нематод - 1. Как видно, из 113 родов в число ведущих попали всего $8(7,1 \%)$ родов. Из них три рода включали 10 и более видов. Суммарная доля их в гельминтофауне составила $28,9 \%$ (табл. 3 ).

Таблица 3

Участие ведущих родов в фауне гельминтов водно-болотных птиц Байкальской Сибири

\begin{tabular}{|c|c|c|c|c|}
\hline \multirow{3}{*}{ Классы } & \multirow{2}{*}{ Ведущие роды } & \multicolumn{3}{|c|}{ Количество видов } \\
\cline { 3 - 5 } & & \multirow{2}{*}{ абс. } & доля (\%) в фауне гельминтов \\
\cline { 3 - 5 } & & 10 & региона & в классе \\
\hline \multirow{3}{*}{ Цестода } & Anomotaenia & 15 & 6,1 & 10,6 \\
\cline { 2 - 5 } & Aploparaksis & 6 & 2,5 & 16,0 \\
\cline { 2 - 5 } & Diorchis & 6 & 2,5 & 6,4 \\
\cline { 2 - 5 } & Echinocotyle & 7 & 2,9 & 6,4 \\
\hline \multirow{2}{*}{ Трематода } & Echinoparyphium & 10 & 4,1 & 9,4 \\
\cline { 2 - 5 } & Plagiorchis & 9 & 3,7 & 8,4 \\
\cline { 2 - 5 } & Diplostomum & 7 & 2,9 & 19,4 \\
\hline Нематода & Tetrameres & & & \\
\hline
\end{tabular}


В своих классах доля видов четырех ведущих родов цестод составили $39,4 \%$, трематод - трех родов - 24,3\%, нематод - один род - $19,4 \%$.

Распределение гельминтов по видам хозяев. В таблице 4 показано распределение видового состава гельминтов по видам водно-болотных птиц Байкальской Сибири. Представлено гельминтофауна по 63 трем видам 7 отрядов. Объем материала распределен по видам хозяев весьма неравномерно. Поэтому по многим видам сведения неполны.

Таблий 4

Зараженность гельминтами водно-болотных видов птиц Байкальской Сибири

\begin{tabular}{|c|c|}
\hline Виды птиц & Распределение гельминтов по хозяевам \\
\hline \multicolumn{2}{|r|}{ Отряд Гусеобразные Anseriformes } \\
\hline Огарь & $\begin{array}{l}\text { Цестоды: Diorchis elisae, Fimbriaria fasciolaris; нематоды: Echinuria } \\
\text { uncinata }\end{array}$ \\
\hline Свиязь & $\begin{array}{l}\text { Цестоды: Cloacotaenia megalops; трематоды: Echinoparyphium } \\
\text { baculus, Notocotylus attenuates, N. linearis, Cotylurus cornutus; } \\
\text { нематоды: Epomidiostomum anatinum; скребни: Polymorphus minutus, } \\
\text { Echinuria uncinata }\end{array}$ \\
\hline Касатка & Цестоды: Diorchis bulbodes, Sobolevicanthus gracilis \\
\hline Серая утка & $\begin{array}{l}\text { Цестоды: Unciunia ciliate, Platyscolex ciliate, Aploparaksis furcigera, } \\
\text { A. larina, Cloacotaenia megalops, Dicranotaenia coronula, Diorchis } \\
\text { elisae, D. lintoni, D. ransomi, D. stefanskii, Fimbriaria fasciolaris, } \\
\text { Microsomacanthus abortive, M. compressa, Retinometra longicirrosa, } \\
\text { Sobolevicanthus gracilis; трематоды: Plagiorchis elegans, Echinostoma } \\
\text { revolutum, E. paraulum, Echinoparyphium cleric, E. aconiatum, } \\
\text { Notocotylus attenuates, N. linearis, Apatemon gracilis, Cotylurus } \\
\text { cornutus; нематоды: Amidostomum anseris, Porrocaecum crassum, } \\
\text { Tetrameres fissispina; скребни: Polymorphus minutus, P. magnus, } \\
\text { Echinuria uncinata, Filicollis anatis }\end{array}$ \\
\hline Чирок-свистунок & $\begin{array}{l}\text { Цестоды: Lateriporus cleric, L. skrjabini, L.s teres, Aploparaksis } \\
\text { furcigera, A. larina, Cloacotaenia megalops, Dicranotaenia coronula, } \\
\text { Diorchis ransom, Diploposthe laevis, Echinocotyle rosseteri, E. cleric, } \\
\text { Gastrotaenia dogieli, Microsomacanthus abortive, M. compressa, } \\
\text { Retinometra longicirrosa, Sobolevicanthus gracilis, S. krabbeella, } \\
\text { S. octacantha; трематоды: Plagiorchis arcuatus, Psilotrema } \\
\text { simillimum, P. mediopora, P. spiculigerum, Sphaeridiotrema globulus, } \\
\text { Echinoparyphium recurvatum, E. aconiatum, Notocotylus attenuates, } \\
\text { Apatemon gracilis, Cotylurus cornutus; нематоды: Thominx contorta, } \\
\text { T. anatis, Amidostomum anseris, Epomidiostomum anatinum, Porrocae- } \\
\text { cum crissum, Tetrameres fissispina, T. ryjikowi; скребни: Polymorphus } \\
\text { minutus, Echinuria uncinata, Polymorphus magnus, Filicollis anatis }\end{array}$ \\
\hline
\end{tabular}


Продолжение таблищь 4

\begin{tabular}{|c|c|}
\hline Кряква & $\begin{array}{l}\text { Цестоды: Lateriporus skrjabini, Aploparaksis furcigera, A. larina, } \\
\text { Cloacotaenia megalops, Dicranotaenia coronula, Dicranotaenia sp., } \\
\text { Diorchis bulbodes, D. elisae, D. lintoni, D. ransomi, D. sobolevi, } \\
\text { D. stefanskii, Fimbriaria fasciolaris, Microsomacanthus abortive, } \\
\text { M. compressa, M. parvula, Retinometra longicirrosa, Sobolevicanthus } \\
\text { gracilis, Myxolepis collaris; трематоды: Plagiorchis elegans, } \\
\text { P. arcuatus, Prosthogonimus cuneatus, P. ovatus, Psilochasmus oxyurus, } \\
\text { Echinostoma revolutum, E. paraulum, Echinoparyphium baculus, } \\
\text { Hypoderaeum conoideum, Cyclocoelum microstomum, Typhlocoelum } \\
\text { sisowi, Tracheophilus cymbium, Notocotylus attenuates, N. linearis, } \\
\text { Catatropis verrucosa, Diplostomum gavium, D. pusillum, Apatemon, } \\
\text { gracilis, Cotylurus cornutus, Parastrigea anati, Cyathocotyle prussica, } \\
\text { Bilharziella polonica, Dendritobilharzia pulverulenta; нематоды: } \\
\text { Amidostomum acutum, Epomidiostomum anatinum, E. uncinatum, } \\
\text { Porrocaecum crissum, Tetrameres fissispina; } \\
\text { cкребни: Polymorphus minutus, P. acutis, P. magnus, Echinuria uncinata, } \\
\text { Filicollis anatis }\end{array}$ \\
\hline Черная кряква & $\begin{array}{l}\text { Трематоды: Echinostoma revolutum, Cotylurus cornutus; } \\
\text { скребни: Polymorphus minutus, Echinuria uncinata }\end{array}$ \\
\hline Шилохвость & $\begin{array}{l}\text { Трематоды: Echinoparyphium cleric, E. recurvatum; } \\
\text { скребни: Polymorphus magnus }\end{array}$ \\
\hline Чирок-трескунок & Трематоды: Echinoparyphium baculus, Apatemon gracilis \\
\hline Широконоска & $\begin{array}{l}\text { Цестоды: Cloacotaenia megalops, Dicranotaenia coronula, Diorchis } \\
\text { bulbodes, D. ransomi, Diploposthe laevis, Echinocotyle cleric, Fimbriaria } \\
\text { fasciolaris, Gastrotaenia dogieli, Retinometra skrjabini, Skrjabinoparaksis } \\
\text { tatianae, Sobolevicanthus krabbeella, S. octacantha; трематоды: } \\
\text { Petasiger megacanthum, Cyclocoelum microstomum, Notocotylus } \\
\text { attenuates, Catatropis verrucosa, Cotylurus cornutus; нематоды: } \\
\text { Porrocaecum crissum; cкребни: Polymorphus minutus, P. magnus, } \\
\text { Echinuria uncinata, Filicollis anatis }\end{array}$ \\
\hline $\begin{array}{l}\text { Красноголовый } \\
\text { нырок }\end{array}$ & $\begin{array}{l}\text { Цестоды: Aploparaksis furcigera, A. larina, Cloacotaenia megalops, } \\
\text { Diorchis bulbodes, D. lintoni, D. ransomi, D. sobolevi, D. stefanskii, } \\
\text { Diploposthe laevis, Fimbriaria fasciolaris, Gastrotaenia dogieli, } \\
\text { Microsomacanthus abortiva; трематоды: Plagiorchis maculosus, } \\
\text { P. nyrocae, Prosthogonimus sudarikowi, Sphaeridiotrema globulus, } \\
\text { Echinostoma revolutum, E. turkestanicum, Echinoparyphium cleric, } \\
\text { E.recurvatum, E. baculus, Petasigermegacanthum, Notocotylus attenuates, } \\
\text { N. linearis, Apatemon gracilis, Cotylurus cornutus, Cyathocotyle prussica; } \\
\text { нематоды: Amidostomum anseris, Epomidiostomum anatinum; скребни: } \\
\text { Polymorphus minutus, P. magnus, Echinuria uncinata, Filicollis anatis }\end{array}$ \\
\hline $\begin{array}{l}\text { Хохлатая чернеть } \\
\text { Aythya fuligula }\end{array}$ & $\begin{array}{l}\text { Цестоды: Unciunia ciliate, Lateriporus skrjabini, L. teres, Platyscolex } \\
\text { ciliate, Aploparaksis furcigera, A. larina, Cloacotaenia megalops, } \\
\text { Dicranotaenia coronula, Diorchis bulbodes, D. elisae, D. ransomi, } \\
\text { D. sobolevi, D. stefanskii, Diploposthe laevis, Echinocotyle rosseteri, } \\
\text { E. cleric, Gastrotaenia dogieli, Microsomacanthus parvula, } \\
\text { Sobolevicanthus gracilis; трматоды: Plagiorchis elegans, Echinostoma } \\
\text { paraulum, Echinoparyphium cleric, E. recurvatum, E. aconiatum, } \\
\text { Typhlocoelum sisowi, Tracheophilus cymbium, Notocotylus attenuate, } \\
\text { Apatemon gracilis, Cotylurus cornutus, Opisthorchis simulans; } \\
\text { нематоды: Amidostomum anseris; скребни: Polymorphus minutus, } \\
\text { P. magnus, Echinuria uncinata, Filicollis anatis }\end{array}$ \\
\hline
\end{tabular}


Продолжение таблицьь 4

\begin{tabular}{|c|c|}
\hline $\begin{array}{l}\text { Горбоносый } \\
\text { турпан }\end{array}$ & $\begin{array}{l}\text { Цестоды: Diorchis ransomi; скребни: Echinuria uncinata, Polymorphus } \\
\text { acutis }\end{array}$ \\
\hline Гоголь & $\begin{array}{l}\text { Цестоды: Cloacotaenia megalops, Sobolevicanthus gracilis, S. fragi- } \\
\text { lis; трематоды: Echinoparyphium recurvatum, Apatemon gracilis; } \\
\text { нематоды: Porrocaecum crassum; скребни: Polymorphus minutus, } \\
\text { P. acutis, P. magnus, Echinuria uncinata, }\end{array}$ \\
\hline Луток & $\begin{array}{l}\text { Цестоды: Microsomacanthus paramicrosoma; трематоды: Prosthogo- } \\
\text { nimus anatinus, Notocotylus attenuates, N. gibbus, Diplostomum } \\
\text { pusillum, D. mergi, Apatemon gracilis, Cotylurus cornutus; нематоды: } \\
\text { Porrocaecum crissum; скребни: Polymorphus minutus, P. magnus, } \\
\text { Echinuria uncinata }\end{array}$ \\
\hline $\begin{array}{l}\text { Длиннон } \\
\text { крохаль }\end{array}$ & $\begin{array}{l}\text { Цестоды: Diphyllobothrium dendriticum, Ligula intestinalis Schisto- } \\
\text { cephalus solidus Fimbriaria fasciolaris; трематоды: Apatemon fuligulae }\end{array}$ \\
\hline Большой крохаль & $\begin{array}{l}\text { Цестоды: Diphyllobothrium dendriticum, Ligula intestinalis, Schisto- } \\
\text { cephalus solidus, S. nemachili, Fimbriaria fasciolaris; нематоды: } \\
\text { Eustrongylides mergorum, Diplostomum mergi; скребни: Polymorphs } \\
\text { magnus }\end{array}$ \\
\hline \multicolumn{2}{|c|}{ Отряд Гагарообразные Gaviiformes } \\
\hline $\begin{array}{l}\text { Краснозобая } \\
\text { гагара }\end{array}$ & $\begin{array}{l}\text { Цестоды: Diphyllobothrium dendriticum, D.ditremum, Ligula colymbi, } \\
\text { Schistocephalus solidus, Tetrabothrius macrocephalus, Dubininolepis } \\
\text { rostellata; нематоды: Contracaecum spiculigerum, Streptocara } \\
\text { crassicauta }\end{array}$ \\
\hline $\begin{array}{l}\text { Чернозобая } \\
\text { гагара }\end{array}$ & $\begin{array}{l}\text { Цестоды: Diphyllobothrium dendriticum; нематоды: Contracaecum } \\
\text { spiculigerum, Streptocara crassicauta }\end{array}$ \\
\hline \multicolumn{2}{|c|}{ Отряд Пеликанообразные Pelecaniformes } \\
\hline Большой баклан & $\begin{array}{l}\text { Цестоды: Ligula intestinalis, L. colymbi, Paradilepis scolecina, } \\
\text { Pseudanomotaenia micracantha; трематоды: Echinoparyphium } \\
\text { macrovitellatum, Petasiger neocomense; нематоды: Contracaecum } \\
\text { spiculigerum }\end{array}$ \\
\hline \multicolumn{2}{|c|}{ Отряд Аистообразные Ciconiiformes } \\
\hline Серая цапля & $\begin{array}{l}\text { Цестоды: Gryporhynchus pusillus; трематоды: Clinostomum com- } \\
\text { planatum, Petasiger aerates, P. spasskyi, Apharyngostrigea cornu; } \\
\text { нематоды: Desmidocercella numidica }\end{array}$ \\
\hline \multicolumn{2}{|c|}{ Отряд Поганкообразные Podicipediformes } \\
\hline Чомга & $\begin{array}{l}\text { Цестоды: Diphyllobothrium dendriticum, Ligula intestinalis, L. colymbi, } \\
\text { Digramma interrupta, Schistocephalus solidus, S. nemachili, Lateriporus } \\
\text { clerci, Platyscolex ciliate, Confluaria furcifera, C. podicipina, Diorchis } \\
\text { ransomi, Tatria biremis, Cladotaenia globifera; трематоды: Plagiorchis } \\
\text { laricola, Sphaeridiotrema globulus, Renicola pinguis, Echinostoma } \\
\text { revolutum, E. paraulum, Echinoparyphium cleric, Petasiger neocomense, } \\
\text { P. megacanthum, P. skrjabini, P. aerates, Echinochasmus spinulosus, } \\
\text { E. coaxatus, Heterophyes heterophyes, Notocotylus attenuatus, } \\
\text { Prosthogonimus cuntatus, P. ovatus, Diplostomum gavium, Tylodelphys } \\
\text { clavata, T. conifer, Apharyngostrigea cornu, Cotylurus cornutus, C. errati- } \\
\text { cus, Ophiosoma patagiatum, Duboisia teganuma, Bilharziella polonica; } \\
\text { нематоды: Epomidiostomum uncinatum, Contracaecum spiculigerum, } \\
\text { Tetrameres numenii, T. skrjabini, Streptocara crassicauta; } \\
\text { скребни: Polymorphus minutus, P. magnus, Echinuria uncinata }\end{array}$ \\
\hline
\end{tabular}


Продолжение таблицьь 4

\begin{tabular}{|c|c|}
\hline $\begin{array}{l}\text { Черношейная } \\
\text { поганка }\end{array}$ & $\begin{array}{l}\text { Цестоды: Tatria biremis, Cladotaenia globifera; трематоды: Echino- } \\
\text { stoma revolutum, Prosthogonimus ovatus, Cotylurus erraticus, } \\
\text { Diplostomum gavium; нематоды: Tetrameres numenii, T. skrjabini; } \\
\text { скребни: Polymorphus minutus }\end{array}$ \\
\hline $\begin{array}{l}\text { Красношейная } \\
\text { поганка }\end{array}$ & $\begin{array}{l}\text { Цестоды: Diphyllobothrium dendriticum, Tetrabothrius macrocephalus, } \\
\text { Lateriporus cleric, Confluaria furcifera; трематоды: Echinostoma } \\
\text { paraulum, Echinoparyphium cleric, Petasiger megacanthum, Cotylurus } \\
\text { erraticus; нематоды: Contracaecum spiculigerum, Tetrameres numenii, } \\
\text { T. skrjabini; скребни: Polymorphus minutus, Echinuria uncinata }\end{array}$ \\
\hline \multicolumn{2}{|c|}{ Отряд Журавлеобразные Gruiformes } \\
\hline Лысуха & $\begin{array}{l}\text { Цестоды: Diorchis ransomi, D. sobolevi, D. stefanskii; } \\
\text { трематоды: Notocotylus attenuates, N. gibbus, Apatemon glacilis; } \\
\text { нематоды: Porrocaecum crassum; } \\
\text { скребни: Polymorphus minutus, P. magnus, Filicollis anatis, Echinuria } \\
\text { uncinata }\end{array}$ \\
\hline \multicolumn{2}{|c|}{ Отряд Ржанкообразные Charadriiformes } \\
\hline Чибис & $\begin{array}{l}\text { Цестоды: Anomotaenia microphallos, A. microrhyncha, A. stentorea, } \\
\text { A. tringae, Echinocotyle magnisaccis, E. uralensis, Wardium fusa; } \\
\text { трематоды: Leucochloridium actitis, Prosthogonimus ovatus, } \\
\text { Echinoparyphium cleric, E. recurvatum, E. nordiana, Echinostoma } \\
\text { paraulum, Longicollia echinata, Cyclocoelum brasilianum, C. tringae, } \\
\text { C. mutabile, Uvitellina adelphus, U. vanelli, Notocotylus linearis, } \\
\text { Cotylurus cornutus } \\
\text { нематоды: Porrocaecum ensicaudatum, P. semiteres, Contracaecum } \\
\text { spiculigerum, Tetrameres fissispina }\end{array}$ \\
\hline $\begin{array}{l}\text { Бурокрылая } \\
\text { ржанка }\end{array}$ & $\begin{array}{l}\text { Цестоды: Anomotaenia globulus, A. microphallos, Liga brevis; } \\
\text { нематоды: Thominx limicolae, Porrocaecum semiteres }\end{array}$ \\
\hline Галстучник & $\begin{array}{l}\text { Цестоды: Anomotaenia mollis, A.tringae; трематоды: Tanaisia } \\
\text { fedtschenkoi, Plagiorchis nyrocae, P. nanus, Uvitellina adelphus; } \\
\text { нематоды: Eucoleus trilobus, Porrocaecum semiteres, Tetrameres dubia }\end{array}$ \\
\hline Малый зуек & $\begin{array}{l}\text { Цестоды: Panuwa guiarti, Polycercus paradoxa, Pseudanomotaenia } \\
\text { paramicrorhyncha, Anomotaenia clavigera, A. citrus, A. mollis, } \\
\text { A. tringae, Aploparaksis sachalinensis, A. sanjuanensis A. crassirostris; } \\
\text { трематоды: Leucochloridium actitis, Tanaisia fedtschenkoi, Plagior- } \\
\text { chis nanus, Uvitellina adelphus; нематоды: Eucoleus trilobus }\end{array}$ \\
\hline Камнешарка & $\begin{array}{l}\text { Трематоды: Parorchis gedoelsti, Cyclocoelum mutabile; } \\
\text { нематоды: Strongyloides turkmenica }\end{array}$ \\
\hline Вальдшнеп & $\begin{array}{l}\text { Цестоды: Anomotaenia citrus; нематоды: Thominx limicolae, Syngamus } \\
\text { gibbocephalus, Porrocaecum semiteres, Tetrameres dubia, T. araliensis }\end{array}$ \\
\hline Азиатский бекас & $\begin{array}{l}\text { Цестоды: Polycercus paradoxa Pseudanomotaenia paramicrorhyncha, } \\
\text { Anomotaenia citrus, A. ancora, A. tringae, Aploparaksis sachalinensis, } \\
\text { A.filum, A. sanjuanensis, A.crassirostris, Echinocotylenitida, Nadejdolepis } \\
\text { nitida; трематоды: Leucochloridium actitis, Tanaisia fedtschenkoi, } \\
\text { Plagiorchis nanus, Echinostoma stantschinskii, Echinoparyphium politum, } \\
\text { Longicollia echinata, Cyclocoelum mutabile; нематоды: Thominx } \\
\text { limicolae, Syngamus gibbocephalus, Porrocaecum semiteres, Tetrameres } \\
\text { dubia, T. araliensis }\end{array}$ \\
\hline Лесь & Tpe \\
\hline
\end{tabular}


Продолжение таблииьы 4

\begin{tabular}{|c|c|}
\hline Бекас & $\begin{array}{l}\text { Цестоды: Anomotaenia citrus, Aploparaksis sachalinensis, A. sanjua- } \\
\text { nensis, A. mamaevi, A. spinosus, A. crassirostris, A. secessivus, } \\
\text { Nadejdolepis nitida; трематоды: Tanaisia fedtschenkoi, Plagiorchis } \\
\text { nanus, Prosthogonimus cuneatus, Echinoparyphium politum, Longicollia } \\
\text { echinata, Cyclocoelum mutabile; нематоды: Thominx limicolae, } \\
\text { Syngamus gibbocephalus, Porrocaecum semiteres, Tetrameres araliensis }\end{array}$ \\
\hline $\begin{array}{l}\text { Азиатский } \\
\text { бекасовидный } \\
\text { веретенник }\end{array}$ & Нематоды: Cosmocephalus obvelatus \\
\hline $\begin{array}{l}\text { Большой } \\
\text { веретенник }\end{array}$ & $\begin{array}{l}\text { Цестоды: Echinocotylemagnisaccis; трематоды: Plagiorchisuhlwormi, } \\
\text { Prosthogonimus cuneatus, Longicollia echinata, Cyclocoelum tringae, } \\
\text { C. mutabile, Uvitellina vanelli, Echinostoma paraulum; нематоды: } \\
\text { Cosmocephalus obvelatus }\end{array}$ \\
\hline $\begin{array}{l}\text { Малый } \\
\text { веретенник }\end{array}$ & $\begin{array}{l}\text { Цестоды: Echinocotyle nitida, Nadejdolepis nitida; Passerilepis crenata; } \\
\text { трематоды: Plagiorchis nanus }\end{array}$ \\
\hline $\begin{array}{l}\text { Кроншнеп- } \\
\text { малютка }\end{array}$ & $\begin{array}{l}\text { Цестоды: Dilepis undula, Anomotaenia nymphaea, Aploparaksis } \\
\text { crassirostris; трематоды: Leucochloridium actitis, Plagiorchis nanus, } \\
\text { P. uhlwormi, Prosthogonimus cuneatus, Echinostoma revolutum; } \\
\text { нематоды: Thominx limicolae, Tetrameres numenii }\end{array}$ \\
\hline $\begin{array}{l}\text { Средний } \\
\text { кроншнеп }\end{array}$ & Цестоды: Anomotaenia nymphaea \\
\hline $\begin{array}{l}\text { Большой } \\
\text { кроншнеп }\end{array}$ & $\begin{array}{l}\text { Цестоды: Anomotaenia nymphaea; трематоды: Leucochloridium } \\
\text { actitis, Plagiorchis nanus, P. uhlwormi, Prosthogonimus cuneatus, } \\
\text { Schistogonimus rarus; нематоды: Tetrameres numenii }\end{array}$ \\
\hline Щеголь & $\begin{array}{l}\text { Цестоды: Anomotaenia citrus, Aploparaksis sachalinensis; } \\
\text { трематоды: Plagiorchis nanus, Cyclocoelum brasilianum; } \\
\text { нематоды: Tetrameres dubia, Cosmocephalus capellae, C. obvelatus }\end{array}$ \\
\hline Поручейник & $\begin{array}{l}\text { Цестоды: Kowalewskiella longiannulata; трематоды: Echinopary- } \\
\text { phium cleric, Longicollia echinata, Cyclocoelum tringae, C. mutabile; } \\
\text { нематоды: Thominx contorta, Cosmocephalus capellae }\end{array}$ \\
\hline Большой улит & $\begin{array}{l}\text { Цестоды: Anomotaenia clavigera, A. citrus, A. tringae, Aploparaksis } \\
\text { sachalinensis, A. filum, A. sanjuanensis; трематоды: Leucochloridium } \\
\text { actitis, Tanaisia fedtschenkoi, Parorchis gedoelsti, Plagiorchis nanus, } \\
\text { Prosthogonimus cuneatus, Cyclocoelum mutabile, Uvitellina vanelli; } \\
\text { нематоды: Thominx contorta, Strongyloides turkmenica, Syngamus } \\
\text { anterogonimus, Contracaecum spiculigerum, Tetrameres dubia, Cosmo- } \\
\text { cephalus obvelatus, Schistorophus cornutus, Streptocara crassicauda }\end{array}$ \\
\hline Черныш & $\begin{array}{l}\text { Цестоды: Anomotaenia globulus, Aploparaksis sachalinensis, A. filum, } \\
\text { A. orientalis, A. oschmarini, A. secessivus; трематоды: Tanaisia } \\
\text { fedtschenkoi, Plagiorchis vitellatus, P. nyrocae, P. nanus, Prosthogonimus } \\
\text { cuneatus, P. ovatus, Echinoparyphium cleric, E. recurvatum, E. aconiatum, } \\
\text { E. nordiana, E. politum, Cyclocoelum mutabile, Notocotylus linearis, } \\
\text { Diplostomum gasterostei, D. mergi; } \\
\text { нематоды: Strongyloides turkmenica, Tetrameres dubia }\end{array}$ \\
\hline
\end{tabular}


Продолжение таблищь 4

\begin{tabular}{|l|l|}
\hline Фифи & Цестоды: Dilepis glareola, Pseudanomotaenia paramicrorhyncha, \\
& Anomotaenia clavigera, A. citrus, A. tringae, Aploparaksis hirsute, \\
A. sachalinensis, A. filum, A. sanjuanensis, A. mamaevi, A. crassirostris, & A. secessivus; трематоды: Lencochloridium actitis, Tanaisia fedtschen- \\
& koi, Plagiorchis vitellatus, P. nyrocae, P. nanus, Prosthogonimus ovatus, \\
Echinoparyphium aconiatum, E. nordiana, E. politum Cyclocoelum \\
mutabile, Notocotylus linearis, Cotylurus cornutus; нематоды: \\
Thominx contorta, Strongyloides turkmenica, Syngamus anterogonimus, \\
Porrocaecum semiteres, Contracaecum spiculigerum, Tetrameres dubia, \\
Cosmocephalus obvelatus, Schistorophus cornutus
\end{tabular}


Продолжение таблиц̧ь 4

\begin{tabular}{|c|c|}
\hline Краснозобик & $\begin{array}{l}\text { Цестоды: Pseudanomotaenia paramicrorhyncha, Anomotaenia tringae, } \\
\text { Trichocephaloides megalocephala, Aploparaksis sachalinensis, A. crassi- } \\
\text { rostris; трематоды: Plagiorchis nanus Cyclocoelum brasilianum; } \\
\text { нематоды: Contracaecum spasskyi, Tetrameres dubia }\end{array}$ \\
\hline Чернозобик & Цестоды: Trichocephaloides megalocephala, Aploparaksis diagonalis \\
\hline $\begin{array}{l}\text { Острохвостый } \\
\text { песочник }\end{array}$ & $\begin{array}{l}\text { Цестоды: Aploparaksis sachalinensis, A. sanjuanensis; } \\
\text { трематоды: Plagiorchis nanus; нематоды: Tetrameres dubia }\end{array}$ \\
\hline Турухтан & $\begin{array}{l}\text { Цестоды: Pseudanomotaenia paramicrorhyncha, Anomotaenia tringae, } \\
\text { Sacciuterina paradoxa, Aploparaksis crassirostris, Echinocotyle ura- } \\
\text { lensis, Progynotaenia odhneri; трематоды: Leucochloridium actitis, } \\
\text { Plagiorchis vitellatus, P. nanus, Prosthogonimus cuneatus, Echinostoma } \\
\text { revolutum, Echinoparyphium aconiatum, E. politum, Cyclocoelum } \\
\text { brasilianum, C. mutabile; нематоды: Syngamus palustris }\end{array}$ \\
\hline Сизая чайка & $\begin{array}{l}\text { Цестоды: Diphyllobothrium dendriticum, D. ditremum, Ligula } \\
\text { intestinalis, L. colymbi, Lateriporus cleric, Paricterotaenia porosa, } \\
\text { P. sternina, Pseudanomotaenia micracantha, P. constricta, Choanotaenia } \\
\text { porosa, Cloacotaenia megalops, Diorchis ransomi, Wardium fusa; } \\
\text { трематоды: Dicrocoelium anatis, Tanaisia fedtschenkoi, Orchipedium } \\
\text { tracheicola, Philophthalmus lucipetus, Pygorchis alakolensis, Erscho- } \\
\text { viorchis lintoni, Plagiorchis elegans, P. laricola, P. multiglandularis, } \\
\text { P. arcuatus, P. maculosus, Prosthogonimus ovatus, Psilotrema } \\
\text { simillimum, Renicola lari, Echinostoma revolutum, Echinoparyphium } \\
\text { cleric, E. recurvatum, Cyclocoelum mutabile, Uvitellina adelphus, } \\
\text { Stictodora sawakinensis, Tetracladium sterna, Heterophyes heterophyes, } \\
\text { Pachytrema paniceum, Notocotylus attenuates, N. lintaris, Diplostomum } \\
\text { chromatophorum, D. rutile, D. helveticum, D. volvens, D. spathaceum, } \\
\text { Cotylurus pileatus, C. platycephalus, Cyathocotyle orientalis Bilharziella } \\
\text { polonica Ornithobilharzia canaliculata; нематоды: Thominx contorta, } \\
\text { Contracaecum spiculigerum, Tetrameres fissispina, T. numenii, T. skrja- } \\
\text { bini, Schistorophus cornutus, Streptocara crassicauda } \\
\text { cкребни: Polymorphus minutus, P. acutis, P. magnus, Echinuria uncinata, } \\
\text { Corynosoma strumosum }\end{array}$ \\
\hline $\begin{array}{l}\text { Монгольская } \\
\text { чайка }\end{array}$ & $\begin{array}{l}\text { Цестоды: Diphyllobothrium dendriticum, D. ditremum, Ligula } \\
\text { intestinalis, Schistocephalus solidus, Lateriporus gredleri, L. cleric, } \\
\text { L. teres, Paricterotaenia porosa, P. sternina, Pseudanomotaenia micra- } \\
\text { cantha, P. constricta, Choanotaenia porosa, Aploparaksis furcigera, } \\
\text { Cloacotaeniamegalops, Gastrotaeniadogieli, Wardiumfusa; трематоды: } \\
\text { Lyperosomum lari, Tanaisia fedtschenkoi, Orchipedium tracheicola, } \\
\text { Parorchis acanthus, Parorchis sp., Philophthalmus lucipetus, P. skrjabini, } \\
\text { Erschoviorchis lintoni, Metorchis xanthosomus, Metametorchis butoridi, } \\
\text { Plagiorchis elegans, P. laricola, P. multiglandularis, P. arcuatus, P. macu- } \\
\text { losus, Prosthogonimus ovatus, Renicola lari, Echinostoma revolutum, } \\
\text { Echinoparyphium cleric, E. recurvatum, Mesorchis pseudoechinatus, } \\
\text { Typhlocoelum cucumerinum, Stictodora lari, S. sawakinensis, Tetracla- } \\
\text { dium sterna, Heterophyes heterophyes, Pachytrema paniceum, Diplo- } \\
\text { stomum chromatophorum, D. rutile, D. helveticum, D. volvens, } \\
\text { D. spathaceum, Apatemon gracilis, Cotylurus pileatus, C. platycephalus, } \\
\text { Cyathocotyle orientalis, Bilharziella polonica; немamodb: Contracae- } \\
\text { cum spiculigerum, Tetrameres fissispina, T. numenii, T. skrjabini, } \\
\text { Schistorophus cornutus, Streptocara crassicauda, Aprocta turgida; } \\
\text { cкребни: Polymorphus minutus, P. magnus, Echinuria uncinata, } \\
\text { Corynosoma strumosum }\end{array}$ \\
\hline
\end{tabular}


Продолжение таблииы 4

\begin{tabular}{|c|c|}
\hline Озерная чайка & $\begin{array}{l}\text { Цестоды: Diphyllobothrium dendriticum, D. ditremum, Ligula intesti- } \\
\text { nalis, Lateriporus cleric, L. teres, Paricterotaenia porosa, P. sternina, } \\
\text { Choanotaeniaporosa, Cloacotaeniamegalops, Diorchisbulbodes, Wardium } \\
\text { fusa, Philophthalmus lucipetus; трематоды: Erschoviorchis lintoni, } \\
\text { Plagiorchis elegans, P. laricola, P. multiglandularis, Prosthogonimus } \\
\text { ovatus, Echinostoma revolutum, Echinoparyphium cleric, E. recurvatum, } \\
\text { Philophthalmus lucipetus, Petasiger megacanthum, Stictodora } \\
\text { sawakinensis, Pachytrema paniceum, Diplostomum chromatophorum, } \\
\text { D. rutile, D. helveticum, D. volvens, D. spathaceum, Cotylurus pileatus, } \\
\text { C. platycephalus, Holostephanus dubius, Ornithobilharzia canaliculata, } \\
\text { Holostephanus dubius; нематоды: Thominx contorta, Syngamus } \\
\text { anterogonimus, Cyathostoma bronchialis, Contracaecum spiculigerum, } \\
\text { C. microcephalum, Tetrameres fissispina, T. numenii, T. skrjabini, } \\
\text { Schistorophus cornutus, Streptocara crassicauda; скребни: Polymor- } \\
\text { phus minutus, P. magnus, Echinuria uncinata, Corynosoma strumosum }\end{array}$ \\
\hline Малая чайка & $\begin{array}{l}\text { Трематоды: Plagiorchis laricola, Diplostomum helveticum; } \\
\text { скребни: Echinuria uncinata }\end{array}$ \\
\hline Чеграва & $\begin{array}{l}\text { Трематоды: Plagiorchis laricola, Knipowitschetrema ussuriensis, } \\
\text { Tetracladium sterna, Heterophyes heterophyes, Diplostomum helveticum }\end{array}$ \\
\hline Речная крачка & $\begin{array}{l}\text { Цестоды: Lateriporus teres, Choanotaenia porosa; трематоды: } \\
\text { Orchipedium tracheicola, Philophthalmus palpebrarum, Erschoviorchis } \\
\text { lintoni, Plagiorchis elegans, P. laricola, P. multiglandularis, P. brauni, } \\
\text { P. arcuatus, Prosthogonimus ovatus, Psilotrema simillimum, Sphaeri- } \\
\text { diotrema globulus, Echinostoma revolutum, Echinoparyphium cleric, } \\
\text { E. recurvatum, Stictodora sawakinensis, Tetracladium sterna, Diplo- } \\
\text { stomum chromatophorum, D. rutile, D. helveticum, D. spathaceum, } \\
\text { Cotylurus pileatus, C. platycephalus, Bilharziella polonica; } \\
\text { скребни: Polymorphus minutus, P. magnus, Echinuria uncinata }\end{array}$ \\
\hline $\begin{array}{l}\text { Белокрылая } \\
\text { крачка }\end{array}$ & $\begin{array}{l}\text { Трематоды: Orchipedium tracheicola, Philophthalmus palpebrarum, } \\
\text { Pygorchis alakolensis, Erschoviorchis lintoni, Plagiorchis elegans, } \\
\text { P. laricola, P. arcuatus, Echinostoma revolutum, Echinoparyphium cleric, } \\
\text { E. recurvatum, Stictodora sawakinensis, Tetracladium sterna, Diplo- } \\
\text { stomum chromatophorum, D. rutile, D. spathaceum, Cotylurus pileatus, } \\
\text { C. platycephalus, Bilharziella polonica; скребни: Polymorphus minutus, } \\
\text { P. magnus, Echinuria uncinata }\end{array}$ \\
\hline
\end{tabular}

Особенности гельминтофауны отдельных отрядов водно-болотных птиц. Как уже отмечали, объем материала по видам хозяев разный, по многим видам вскрыто мало особей. Учитывая такую ситуацию, мы не стали проводить сравнительный анализ между разными отрядами птиц. Обобщенные количественные показатели фауны гельминтов водно-болотных птиц Байкальской Сибири приведены в таблице 5. Из этих пяти отрядов только по трем группам - гусеобразным, поганкообразным и ржанкообразным, которые изучены относительно лучше, можно провести анализ. Более подробные сведения по каждому виду птиц даны в предыдущих наших статьях [Доржиев, Бадмаева, Дугаров, 2019а,б, 2020а,б]. В наших статьях число видов паразитов некоторых птиц несколько разнится от нижеприведенных, что связано с привлечением дополнительных неопубликованных данных А. В. Некрасова, а также уточнением и исправлением (были допущены некоторые ошибки) общего таксономического списка гельминтов. Таких корректировок немного, и они незначительные. 
Количественные показатели таксономического разнообразия гельминтов водно-болотных птиц Байкальской Сибири

\begin{tabular}{|c|c|c|c|c|c|c|c|}
\hline \multirow[t]{2}{*}{ № } & \multirow{2}{*}{$\begin{array}{c}\text { Названия } \\
\text { отрядов птиц }\end{array}$} & \multirow{2}{*}{$\begin{array}{l}\text { Число } \\
\text { видов }\end{array}$} & \multicolumn{5}{|c|}{ Количество видов гельминтов, абс. } \\
\hline & & & Цестоды & Трематоды & Нематоды & Скребни & Всего \\
\hline 1 & Гусеобразные & 17 & 38 & 39 & 11 & 4 & 92 \\
\hline 2 & Гагарообразные & 2 & 6 & - & 2 & - & 8 \\
\hline 3 & Пеликанообразные & 1 & 4 & 2 & 1 & - & 7 \\
\hline 4 & Аистообразные & 1 & 1 & 4 & 1 & - & 6 \\
\hline 5 & Поганкообразные & 3 & 15 & 25 & 5 & 3 & 48 \\
\hline 6 & Журавлеобразные & 1 & 3 & 3 & 1 & 4 & \\
\hline 7 & $\begin{array}{l}\text { Ржанкообразные: } \\
\text { Подотряд Ржанковые }\end{array}$ & 31 & 36 & 30 & 21 & 1 & 88 \\
\hline & Подотряд Чайковые & 7 & 20 & 52 & 11 & 3 & 86 \\
\hline
\end{tabular}

Гусеобразные. В настоящее время у данного отряда в регионе известно 92 вида гельминтов. Цестоды и трематоды представлены почти одинаково и занимают $83,7 \%$ гельминтофауны. Доля нематодов небольшая (11,9\%), а скребней совсем немного (4,3\%). При сравнении соотношений паразитов разных классов у разных подсемейств гусеобразных (речных и нырковых уток и крохалей) показатели мало отличались [Доржиев, Бадмаева, Дугаров, 2019а].

Ни один из видов гельминтов не паразитировал во всех видах гусеообразных, лишь некоторые виды отмечались максимально у 7-9 хозяев. Так, среди цестод от 4 до 8 хозяев имели 13 (34,2\%) видов: Aploparaksis furcigera (5 хозяев), Aploparaksis larina (5), Cloacotaenia megalops (8), Dicranotaenia coronula (5), Diorchis bulbodes (5), Diorchis elisae (4), Diorchis ransomi (7), Diorchis stefanskii (4), Diploposthe laevis (4), Fimbriaria fasciolaris (7), Gastrotaenia dogieli (4), Microsomacanthus abortiva (4), Sobolevicanthus gracilis (6).

У трематод наблюдается такая же картина, 8 (20,5\%) видов располагались в 4-9 хозяевах: Apatemon gracilis (8 хозяев), Cotylurus cornutus (9), Echinoparyphium baculus (4), Echinoparyphium clerci (4), Echinoparyphium recurvatum (5), Echinostoma revolutum (4), Notocotylus attenuates (8), Notocotylus linearis (4).

Среди нематод 4-6 хозяев имели Amidostomum anseris (4), Epomidiostomum anatinum (4), Porrocaecum crassum (6).

Нами подсчитан коэффициент видового сходства по Серенсену в разных подсемействах гусеобразных птиц и выявлено, что показатели их относительно низкие, максимально доходит до 30\%, реже выше при попарном сравнении видов утиных [Доржиев, Бадмаева, Дугаров, 2019а].

Поганкообразные. У трех видов поганок обнаружено относительно большое число гельминтов (48). Преобладали трематоды $(52,1 \%)$, почти одну треть составляли цестоды. Нематод и скребней было немного.

Среди гельминтов поганок обнаружилось довольно много специфических паразитов. Так, у всех трех исследованных видов найден сосальщик Cotylurus erraticus, а у чомги и черношейной поганки - ленточные черви Tatria biremis и 
Ц. 3. Доржсиев, Е. Н. Бадмаева, Ж. Н. Дугаров. Гельминты водно-болотных птиц Байкальской Сибири: таксономическое разнообразие и распределение по хозяевам

Cladotaenia globifera, сосальщик Diplostomum gavium, у чомги и красношейной поганки - Confluaria furcifera [Некрасов, Жатканбаева, 1982; Подковыров и др., 1988; Подковыров, Некрасов, Пыжьянов, 1991]. Лишь у чомги выявлены цестоды Digramma interrupta, Confluaria podicipina, трематоды Renicola pinguis, Tylodelphys clavata, T. conifer, Ophiosoma patagiatum Duboisia teganuma, Petasiger neocomense, P. skrjabini, Echinochasmus spinulosus, E. coaxatus, но они, несомненно, найдутся у других видов поганок, поскольку в других регионах у них встречаются.

Ржанкообразные. Из данного отряда изучено два подотряда — подотряд ржанковые Charadrii и подотряд чайковые Laridae. Рассмотрим их по отдельности.

Ржанковые были представлены 31 видом. Выявлено 88 видов гельминтов, из них на цестод приходится 40,9\%, трематод - 34,1\%, нематод - $23,9 \%$ и скребней - лишь 1,1\%. Однако же соотношение представителей разных классов паразитов у разных подсемейств ржанковых птиц заметно отличалось. У отдельных подсемейств (ржанков, бекасовых и песочников) преобладали цестоды, у других (чибисовых, камнешарок, веретенниковых, улитов и плавунчиковых) трематоды (табл. 6).

Таблица 6

Количественные показатели разнообразия гельминтов подсемейств ржанковых птиц Байкальской Сибири

\begin{tabular}{|l|c|c|c|c|c|c|}
\hline \multirow{2}{*}{ Подсемейство } & \multirow{2}{*}{$\begin{array}{c}\text { Число } \\
\text { видов }\end{array}$} & \multicolumn{5}{|c|}{ Количество видов гельминтов, абс. } \\
\cline { 3 - 7 } & птиц & цестоды & трематоды & нематоды & скребни & всего \\
\hline Чибисовые & 1 & 6 & 15 & 3 & 0 & 24 \\
\hline Ржанки & 3 & 14 & 8 & 5 & 0 & 27 \\
\hline Камнешарки & 1 & 0 & 2 & 1 & 0 & 3 \\
\hline Бекасовые & 4 & 14 & 8 & 4 & 0 & 26 \\
\hline Веретенниковые & 6 & 7 & 10 & 2 & 15 & 20 \\
\hline Улиты & 8 & 19 & 26 & 14 & 0 & 59 \\
\hline Плавунчики & 1 & - & 3 & - & 0 & 3 \\
\hline Песочники & 7 & 19 & 12 & 7 & 0 & 38 \\
\hline
\end{tabular}

Большое число паразитов имели такие виды, как кулик-воробей, фифи, мородунка. Широкое распространение среди ржанковых птиц имели цестоды Aploparaksis sachalinensis, Anomotaenia tringae, Aploparaksis crassirostris, Anomotaenia citrus, трематоды Plagiorchis nanus, Cyclocoelum mutabile, Leucochloridium actitis, Echi noparyphium politum, Plagiorchis vitellatus, нематоды Tetrameres dubia Porrocae cum semiteres. Выявлено немало специфических для ржанковых птиц гельминтов (род Anomotaenia - A. citrus, A. globulus, A. tringae и др., Pseudanomotaenia paramicrorhyncha, Trichocephaloides megalocephala, Aploparaksis sachalinensis и др.).

Число хозяев у разных видов гельминтов составляет от 1 до 18: у цестод - 1-10 хозяев, трематод - 1-18, нематод - 1-12. Большинство видов паразитов имеет $1-3$ хозяев: у цестод - 66,7\%, трематод - 60,0, нематод - 76,2. При этом четвертая часть гельминтов выявлена у одного хозяина, чуть больше - у двух хозяев. Сосальщики по сравнению с другими классами обладают несколько большим 
числом хозяев, в частности доля видов, паразитирующих у 5 хозяев, достигала 13,3\% [Доржиев, Бадмаева, Дугаров, 2019б].

Подотряд чайковые представлен здесь 7 видами. Зарегистрировано у них 86 видов гельминтов, у чаек - 82 вида, крачек - 32 (табл. 7). Более половины $(58,5 \%)$ видового состава паразитофауны чайковых относится к классу трематод, у крачек доля их заметно выше $(87,5 \%)$, но по числу видов намного меньше. У чаек не выявлено 4 вида (Philophthalmus palpebrarum, Plagiorchis brauni, Sphaeridiotrema globulus, Knipowitschetrema ussuriensis), которые оказались у крачек.

Таблица 7

Количественные показатели разнообразия гельминтов подсемейств чайковых птиц Байкальской Сибири

\begin{tabular}{|l|c|c|c|c|c|c|}
\hline \multirow{2}{*}{ Группы птиц } & \multirow{2}{*}{\begin{tabular}{c} 
Число \\
видов \\
\cline { 3 - 8 }
\end{tabular}} & \multicolumn{5}{|c|}{ Количество видов гельминтов, абс. } \\
\cline { 3 - 8 } & цестод & трематод & нематод & скребней & всего \\
\hline Подсемейство чайки & 4 & 20 & 48 & 11 & 3 & 82 \\
\hline Подсемейство крачки & 3 & 2 & 28 & 0 & 2 & 32 \\
\hline Подотряд чайковые & 7 & 20 & 52 & 11 & 3 & 86 \\
\hline
\end{tabular}

В целом цестоды у чайковых занимают одну четвертую часть $(23,0 \%)$ фауны гельминтов. При этом доля их у чаек $(24,4 \%)$ намного выше, чем у крачек $(6,3 \%)$. У чаек и крачек заметно отличается степень зараженности цестодами и трематодами. Крачки больше заражены трематодами и очень мало цестодами. У чаек число видов трематод почти в 2,5 раза больше, чем цестод.

Нематоды представлены относительно небольшой долей $(12,6 \%)$, все они паразитировали в чайках, у крачек они не обнаружены. Скребней отмечено всего по 3 вида у обеих групп птиц (в долях у чаек $3,7 \%$, крачек -6,3\%).

Между чайками и крачками коэффициент сходства по цестодам очень низкий, по трематодам немного выше. По скребням из трех видов, отмеченных у чаек, два вида обнаружены у крачек, отсюда индекс сходства оказался относительно высоким (66,7\%) [Доржиев, Бадмаева, Дугаров, 2020а].

\section{Заключение}

Результаты исследований гельминтов водно-болотных птиц Байкальской Сибири показывают, что в целом паразиты гидрофильных птиц региона изучены слабо. Приведенный материал охватывает чуть более $10 \%$ видового состава водно-болотных птиц Байкальской Сибири. Более того, по многим из изученных видов объем материала недостаточный.

В настоящее время установлено у водно-болотных птиц региона 243 вида гельминтов из 47 семейств, 113 родов. При сравнении с литературными данными из других регионов по большинству видов, особенно из отрядов гусеобразных, поганкообразных, ржанкообразных и других, видно, что предстоит выявить еще много видов гельминтов.

Надеемся, что представленный материал будет полезным при дальнейших исследованиях паразитов птиц не только Байкальской Сибири, но и в целом Северной и Центральной Азии. 
Ц. 3. Доржсиев, Е. Н. Бадмаева, Ж. Н. Дугаров. Гельминты водно-болотных птиц Байкальской Сибири: таксономическое разнообразие и распределение по хозяевам

\section{Литература}

1. Атрашкевич Г. И. Вклад Центра паразитологии ИПЭЭ РАН / Гельминтологической лаборатории АН СССР в изучение гельминтов птиц Якутии // Биоразнообразие паразитов. Москва : Товарищество научных изданий КМК, 2018. С. 22-24. Текст : непосредственный.

2. Атрашкевич Г. И., Сонин М. Д.. Скребни (Acanthocephala) птиц низовья Оби // Основные достижения и перспективы развития паразитологии. Москва : ИНП РАН, 2004. С. 37-38. Текст : непосредственный.

3. Балданова Д. Р., Пронин Н. М. Скребни (тип Acanthocephala) Байкала. Морфология и экология. Новосибирск : Наука, 2001. 158 с. Текст : непосредственный.

4. Белопольская М. М. Трематоды куликов устья р. Лены // Материалы к научной конференции ВОГ. 1971. Вып. 23. С. 40-49. Текст : непосредственный.

5. Быховская-Павловская И. Е. Трематоды птиц фауны СССР (эколого-географический обзор). Москва ; Ленинград : Изд-во АН СССР, 1962. 407 с. Текст : непосредственный.

6. Быховская-Павловская И. Е. Фауна сосальщиков птиц Западной Сибири и ее динамика // Паразитологический сборник Зоологического института АН СССР. 1953. Т. 15. С. 1-116. Текст : непосредственный.

7. Быховская-Павловская И. Е., Рыжиков К. М. Шистосоматиды гусиных птиц Якутии // Паразитологический сборник Зоологического института АН СССР. 1958. Т. 18. С. 281-294.

8. Видовая структура гельминтофаун субпопуляций серебристой чайки как отражение особенностей их ценотических связей в основных районах гнездования на оз. Байкал / Н. М. Пронин, А. В. Некрасов, С. Д. Санжиева, Т. М. Тимошенко // Современные проблемы орнитологии Сибири и Центральной Азии: материалы I Международной орнитологической конференции. Улан-Удэ, 2000. С.137-139. Текст : непосредственный.

9. Гельминты птиц Якутии и сопредельных территорий (нематоды и акантоцефалы) / К. М. Рыжиков, Н. М. Губанов, Л. М. Толкачёва [и др.]. Москва : Наука, 1973. 204 с. Текст : непосредственный.

10. Гельминты птиц Якутии и сопредельных территорий (цестоды и трематоды) / К. М. Рыжиков, Н. М. Губанов, Л. М. Толкачева [и др.]. Москва : Наука, 1974. 340 с. Текст : непосредственный.

11. Губанов Н. М. Гельминтофауна гагар Якутии // Вредные насекомые и гельминты Якутии. Якутск, 1971. С. 85-95. Текст : непосредственный.

12. Губанов Н. М., Сергеева Т. П. К фауне гельминтов чаек Якутии // Вредные насекомые и гельминты Якутии. Якутск, 1971. С. 96-101. Текст : непосредственный.

13. Губанов Н. М., Федоров К. П. Скребни охотничье-промысловых птиц Якутии // Вредные насекомые и гельминты Якутии. Якутск, 1971. С. 85-90. Текст : непосредственный.

14. Динамика зараженности животных гельминтами / Н. М. Пронин, Д.-С. Д. Жалцанова, С. В. Пронина [и др.]. Улан-Удэ : Изд-во БНЦ СО РАН, 1991. 201 с. Текст : непосредственный.

15. Доржиев Ц. 3., Бадмаева Е. Н., Дугаров Ж. Н. Эколого-фаунистический анализ гельминтов водно-болотных птиц Байкальской Сибири: 3. Чайковые Laridae // Природа Внутренней Азии. Nature of Inner Asia. 2020. № 1 (14). С. 66-78. Текст : непосредственный.

16. Доржиев Ц. 3., Бадмаева Е. Н., Дугаров Ж. Н. Эколого-фаунистический анализ гельминтов водно-болотных птиц Байкальской Сибири: 4. Гагаровые, баклановые, цаплевые, поганковые, пастушковые // Природа Внутренней Азии. Nature of Inner Asia. 2020. № 3-4 (16). С. 34-43. Текст : непосредственный.

17. Доржиев Ц. 3., Бадмаева Е. Н., Дугаров Ж. Н. Эколого-фаунистический анализ гельминтов водно-болотных птиц Байкальской Сибири. 1. Утиные Anatidae // Природа Внутренней Азии. The Nature of Inner Asia. 2019. № 1 (10). С. 7-27. Текст : непосредственный. 
18. Доржиев Ц. З., Бадмаева Е. Н., Дугаров Ж. Н. Эколого-фаунистический анализ гельминтов водно-болотных птиц Байкальской Сибири. 2. Ржанковые Charadrii // Природа Внутренней Азии. The Nature of Inner Asia. 2019. № 3 (12). С. 7-32. Текст : непосредственный.

19. Контримавичус В. Л., Бахметьева Т. А. Гельминтофауна гагар низовья р. Лены // Труды ГеЛАН. Москва : Изд-во АН СССР, 1960. Т. 10. С. 124-133. Текст : непосредственный.

20. Мамаев Ю. Л. Гельминтофауна куриных и куликов Восточной Сибири // Труды ГеЛАН. Москва : Изд-во АН СССР, 1959. Т. 9. С. 160-174. Текст : непосредственный.

21. Масарновский А. Г., Скрябин Н. Г. Гельминтологическая характеристика чаек Северного Байкала // Зоопаразитология бассейна озера Байкал. Улан-Удэ, 1979. С. 28-36. Текст : непосредственный.

22. Матевосян Е. М. Дилепидоидеа - ленточные гельминты домашних и диких животных. Т. 3. Основы цестодологии / Акад. наук СССР. Всесоюз. о-во гельминтологов ; под редакцией акад. К. И. Скрябина. Москва: Изд-во Акад. наук СССР, 1963. 687 с. Текст : непосредственный.

23. Некрасов А. В. Гельминты диких птиц бассейна озера Байкал. Улан-Удэ : Изд-во БНЦ СО РАН, 2000. 56 с. Текст : непосредственный.

24. Некрасов А. В. Скребни некоторых птиц Прибайкалья // Экология и охрана птиц и млекопитающих Забайкалья. Улан-Удэ, 1989. С. 53-60. Текст : непосредственный.

25. Некрасов А. В., Жатканбаева Д. Гельминтофауна рыбоядных птиц оз. Байкал // Зоопаразитология Забайкалья. Улан-Удэ, 1982. С. 65-75. Текст : непосредственный.

26. Некрасов А. В., Жатканбаева Д. М. Гельминты рыбоядных птиц оз. Байкал // Зоопаразитология Забайкалья. Улан-Удэ, 1982. С. 65-75. Текст : непосредственный.

27. Некрасов А. В., Пронин Н. М., Дугаров Ж. Н. Трематоды (Plathelminthes, Trematoda). Гл. 9. Аннотированный список фауны озера Байкал и его водосборного бассейна. Т. 1. Озеро Байкал. Новосибирск : Наука, 2001. Кн. 1. С. 271-305. Текст : непосредственный.

28. Некрасов А. В., Санжиева С. Д. Дикие водоплавающие и околоводные птицы о3. Байкал как возможные резерванты гельминтозов домашних уток // Проблемы экологии Прибайкалья. Иркутск, 1988. Ч. 4. С. 133. Текст : непосредственный.

29. Некрасов А. В., Санжиева С. Д. Чайковые птицы озера Гусиное и зараженность гельминтами // Национально-региональные особенности экологического образования и воспитания. Улан-Удэ, 1995. С. 110. Текст : непосредственный.

30. Некрасов А. В., Санжиева С. Д., Егоров В. Г. Гельминтофауна водоплавающих птиц оз. Байкал // Биологические ресурсы Забайкалья и их охрана. Улан-Удэ, 1982. С. 69-81. Текст : непосредственный.

31. Некрасов А. В., Тимошенко Т. М., Санжиева С. Д. Экологические аспекты зараженности гельминтами разных популяций сизой чайки озера Байкал // Гидробиология и гидропаразитология Прибайкалья и Забайкалья. Новосибирск : Наука, 1985. С. 192-209. Текст : непосредственный.

32. Определитель паразитических нематод. Т. 4. Камалланаты, рабдитаты, тиленхаты, трихоцефаляты, диоктофиматы и распределение паразитических нематод по хозяевам / К. И. Скрябин, Н. П. Шихобалова, А. А. Соболев. Москва : Изд-во АН СССР, 1954. 927 с. Текст : непосредственный.

33. Определитель паразитических нематод. Т. 3. Стронгиляты / К. И. Скрябин, Н. П. Шихобалова, Р. С. Шульц [и др.]. Москва : Изд-во АН СССР, 1952. 890 с. Текст : непосредственный.

34. Определитель трематод рыбоядных птиц Палеарктики (брахилаймиды, клиностомиды, циклоцелиды, фасциолиды, нотокотилиды, плагиорхиды, шистосоматиды) / ответственный редактор М. Д. Сонин. Москва : Наука, 1985. 256 с. Текст : непосредственный. 
Ц. З. Доржиев, Е. Н. Бадмаева, Ж. Н. Дугаров. Гельминты водно-болотных птиц Байкальской Сибири: таксономическое разнообразие и распределение по хозяевам

35. Определитель трематод рыбоядных птиц Палеарктики (описторхиды, рениколиды, стригеиды) / АН СССР, Всесоюз. о-во гельминтологов ; ответственный редактор М. Д. Сонин. Москва : Наука, 1986. 216 с. Текст : непосредственный.

36. Определитель трематод рыбоядных птиц Палеарктики / ответственный редактор М. Д. Сонин. Москва, 1986. 213 с. Текст : непосредственный.

37. Подковыров В. А., Некрасов А. В., Пыжьянов С. В. Большая поганка в Чивыркуйском заливе озера Байкал // Экология и фауна птиц Восточной Сибири. Улан-Удэ, 1991. С. 140-147. Текст : непосредственный.

38. Разнообразие гельминтофауны серебристой чайки (Larus argentatus) озера Байкал: особенности пространственного распределения и зараженности / А. В. Некрасов, Н. М. Пронин, С. Д. Санжиева, Т. М. Тимошенко // Паразитология. 1999. Т. 33, вып. 5. С. 426-436. Текст : непосредственный.

39. Рыжиков К. М., Толкачева Л. М. Аколеаты - ленточные гельминты птиц // Основы цестодологии. Москва : Наука. 1981. Т. 10. 216 с. Текст : непосредственный.

40. Санжиева С. Д. Разнообразие, структуры сообществ и экологии цестод лимнофильных птиц озера Байкал : автореферат диссертации на соискание кандидата биологических наук. Улан-Удэ, 2000. С. 174. Текст : непосредственный.

41. Санжиева С. Д., Некрасов А. В. Анализ видового разнообразия цестод семейства Hymenolepididae (Ariola, 1899) водоплавающих птиц Чивыркуйского залива оз. Байкал // Сохранение биологического разнообразия в Байкальском регионе: проблемы, подходы, практика. Улан-Удэ, 1996. С. 9-11. Текст : непосредственный.

42. Сергеева Т. П. К фауне цестод чайковых птиц Азиатской Субарктики // Труды ГеЛАН. 1971. Т. 22. С. 153-161. Текст : непосредственный.

43. Сергеева Т. П. Трематоды чаек северных районов Средней Сибири // Труды ГеЛАН. Москва : Изд-во АН СССР, 1970. Т. 21. С. 88-92. Текст : непосредственный.

44. Скрябин К. И., Шихобалова Н. П., Мозговой А. А. Определитель паразитических нематод. Т. 2. Оксиураты и аскаридаты. Москва : Изд-во АН СССР, 1951. 631 с. Текст : непосредственный.

45. Скрябин К. И., Шихобалова Н. П., Соболев А. А. Определитель паразитических нематод. Т. 1. Спирураты и филяриаты. Москва : Изд-во АН СССР, 1949. 519 с. Текст : непосредственный.

46. Смогоржевская Л. А. Гельминты водоплавающих и болотных птиц фауны Украины. Киев : Наукова думка, 1976. 416 с. Текст : непосредственный.

47. Спасская Л. П. Цестоды птиц СССР. Гименолепидиды. Москва : Наука, 1966. 698 с. Текст : непосредственный.

48. Спасская Л. П., Спасский А. А. Цестоды птиц Тувы. Кишинев : Штиинца, 1971. 252 с. Текст : непосредственный.

49. Тимошенко Т. М. Гельминты чайковых птиц оз. Байкал и структура природного очага дифиллоботриоза : автореферат диссертации на соискание кандидата биологических наук. Алма-Ата, 1990. 17 с. Текст : непосредственный.

50. Тимошенко Т. М., Жатканбаева Д., Некрасов А. В. Редкие виды трематод рыбоядных птиц озера Байкал // Новое в изучении флоры и фауны Байкала и его бассейна. Иркутск, 1988. С. 87-93. Текст : непосредственный.

51. Тупицын И. И., Тимошенко Т. М. О куликах дельты реки Селенги (разнообразие, численность, гельминты). Сохранение биологического разнообразия в Байкальском регионе: проблемы, подходы, практика. Улан-Удэ : Изд-во БНЦ СО РАН, 1996. Т. 2. С. 32-34. Текст : непосредственный.

52. Филимонова Л. В. Трематоды семейства Notocotylidae Luhe, 1909 от гусиных птиц Якутии // Экология и таксономия гельминтов. Москва : Наука, 1973. С. 179-186. Текст : непосредственный. 
53. Шевцов А. А., Заскинд Л. Н. Гельминты и гельминтозы домашних водоплавающих птиц : учебное пособие. Харьков, 1960. 446 с. Текст : непосредственный.

54. Bondarenko S., Kontrimavichus V. Revision of Aploparaksis Clerc, 1903 (Cestoda: Cyclophyllidea, Aploparaksidae), with keys to the species of the genus // Biologija. 2018. Vol. 64. No. 1. P. 1-64.

55. Danzan G. Helminth Fauna of Domestic and Wild Birds of Mongolia // Proceedings of the All Union Institute for Helminthology named after K. S. Skryabin (VIGIS). 1964. No. 11. P. 42-44.

56. Ganzorig S. Check List of Gelminth Parasites of Mongolian Birds // Ornis Mongolica. 2016. V. 4(432). P. 3-28.

57. Ganzorig S., Danzan G. Materials on the helminth fauna of the birds in Huvsgul region // Natural Condition and Resources of Some Regions of Mongolia. Ulaanbaatar, 1990. P. 111-112.

Статья поступила в редакцию 12.03.2021; одобрена после рецензирования 18.03.2021; принята к публикации 30.03.2021.

\section{HELMINTHS IN WETLAND BIRDS OF BAIKAL SIBERIA: TAXONOMIC DIVERSITY AND DISTRIBUTION BY HOSTS}

Ts. Z. Dorzhiev, E. N. Badmaeva, Zh. N. Dugarov

Tsydypzhap Z. Dorzhiev

Dr. Sci. (Biol.), Prof., Dorzhi Banzarov Buryat State University 24a Smolina St., Ulan-Ude 670000, Russia Institute of General and Experimental Biology SB RAS 6 Sakhyanovoy St., Ulan-Ude 670037, Russia tsydypdor@mail.ru

\section{Evgeniya N. Badmaeva}

Cand. Sci. (Biol.), A/Prof.,

Dorzhi Banzarov Buryat State University

24a Smolina St., Ulan-Ude 670000, Russia calidris03@gmail.com

Zhargal N. Dugarov

Cand. Sci. (Biol.),

Institute of General and Experimental Biology SB RAS

6 Sakhyanovoy St., Ulan-Ude 670047, Russia

zhar-dug@biol.bscnet.ru

Abstract. The final article on the helminths in wetland birds of Baikal Siberia presents an analysis of the taxonomic composition of these parasites and their distribution by hosts. The materials concerns 63 species of birds belonging to 7 orders: Anseriformes - 17 species, Gaviiformes - 2 species, Pelecaniformes - 1 species (Great cormorant), Ciconiiformes 1 species (Gray heron), Podicipediformes -3 species, Gruiformes -1 species (Eurasian coot), Charadriiformes - 38 species.

In total, we have identified 243 species of helminths from 4 classes, 47 families, 113 genera in wetland birds of Baikal Siberia. The taxonomically richest class is trematodes - 107 species distributed over 10 orders, 14 families, and 50 genera. The next is the class of cestodes, 
Ц. 3. Доржсиев, Е. Н. Бадмаева, Ж. Н. Дугаров. Гельминты водно-болотных птиц Байкальской Сибири: таксономическое разнообразие и распределение по хозяевам

which have been represented by 94 species from 3 orders, 9 families and 42 genera. We have identified few nematodes - 36 species from 5 orders, 12 families and 18 genera, and far less acanthocephala -5 species representing 1 order, 1 family, and 3 genera.

The species composition of helminths is presented for all 63 species of birds. The lack of material for many species don't not allow us to reveal the general picture of their infestation by helminths; we have received good results only for some species of ducks, grebes, waders and gulls.

Keywords: helminths, cestodes, trematodes, nematodes, worms, parasites of wetland birds, Lake Baikal, Baikal Siberia.

Acknowledgments. The work was carried out with partial financial support from the grant of Dorzhi Banzarov Buryat State University for innovative scientific research in 2021.

For citation

Dorzhiev Ts. Z., Badmaeva E. N., Dugarov Zh. N. Helminths in Wetland Birds of Baikal Siberia: Taxonomic Diversity and Distribution by Hosts. Nature of Inner Asia. 2021; 1(17): 23-65 (In Russ.). DOI: 10.18101/2542-0623-2021-1-23-65

The article was submitted 12.03.2020; approved after reviewing 18.03.2021; accepted for publication 30.03.2021. 